\title{
Theatrum Anatomicum in History and Today
}

\author{
El Teatrum Anatomicum en la Historia y Hoy
}

Gert-Horst Schumacher

SCHUMACHER, G. H. Theatrum Anatomicum in history and today. Int. J. Morphol., 25(1):15-32, 2007.

SUMMARY:Human cadaveric dissection was introduced in Alexandria around 300 B.C. performed by Herophilos (335-255) for 30 or 40 years. Then it stopped, until Vesalius (1514-1564) began his work during the Renaissance in the Occident. He replaced the dominating theories of Galen (130-201), who had gained his knowledge from animal sections. In the $14^{\text {th }}$ and $15^{\text {th }}$ century human dissections were arranged in small makeshift rooms. Early designs of anatomical theatre were prepared by Alexander Benedictus from Padua 1497 and Carolus Stephanus from Paris 1564. The $1^{\text {st }}$ temporary anatomical theatres arose in Italy in the 16th century, where the term Teatrum Anatomicum came from. In 1594 the 1st permanent anatomical theatre was opened in Padua, that became the model for many anatomical buildings. A most representative type was established in Bologna 1649, but the 1st solitary anatomical theatre originated from Paris 1694. Progress of anatomical knowledge gave birth to the foundation of anatomical institutes in some European countries during the 18th century. They arose in different architecture. Common to all of them was the separation between teaching and research facilities. The stylistic elements came from the axial type, e.g. the Senckenberg Institute in Frankfurt 1776 and the institute of Dorpat (1803-1825/27) and from the Sömmering type the institute in Greifswald (1854/55). Progress of sciences in the $19^{\text {th }}$ century gave impulses for many architectural solutions, this was the German-European type and the Anglo-Saxon-American type. Technical progress of audio-visual equipment caused a new start for the restoration of the auditory to an "Spectatorium" 1872. The auditory was displaced from its central position and changed to a cinema with audio-visual equipment. This was once and for all the end of the traditional eatrum Anatomicum.

KEY WORDS: Medical history; Herophilos; Human anatomical dissection; Galen; Vesalius.

Anatomy belongs to natural sciences because of the subject, which is an integrated part of nature. Detailed factual anatomical knowledge is already documented in the writings of Assyrian and Babylonian astrologists after hepatoskopia, where sacrificed animals were investigated by temple priests, searching the liver and mapping the findings (Fig. 1a ). The liver was known as collecting point of blood and believed as the center of life. Models of terracotta and bronze were used for teaching students to prophesy the future or prognosis (Fig. 1b).

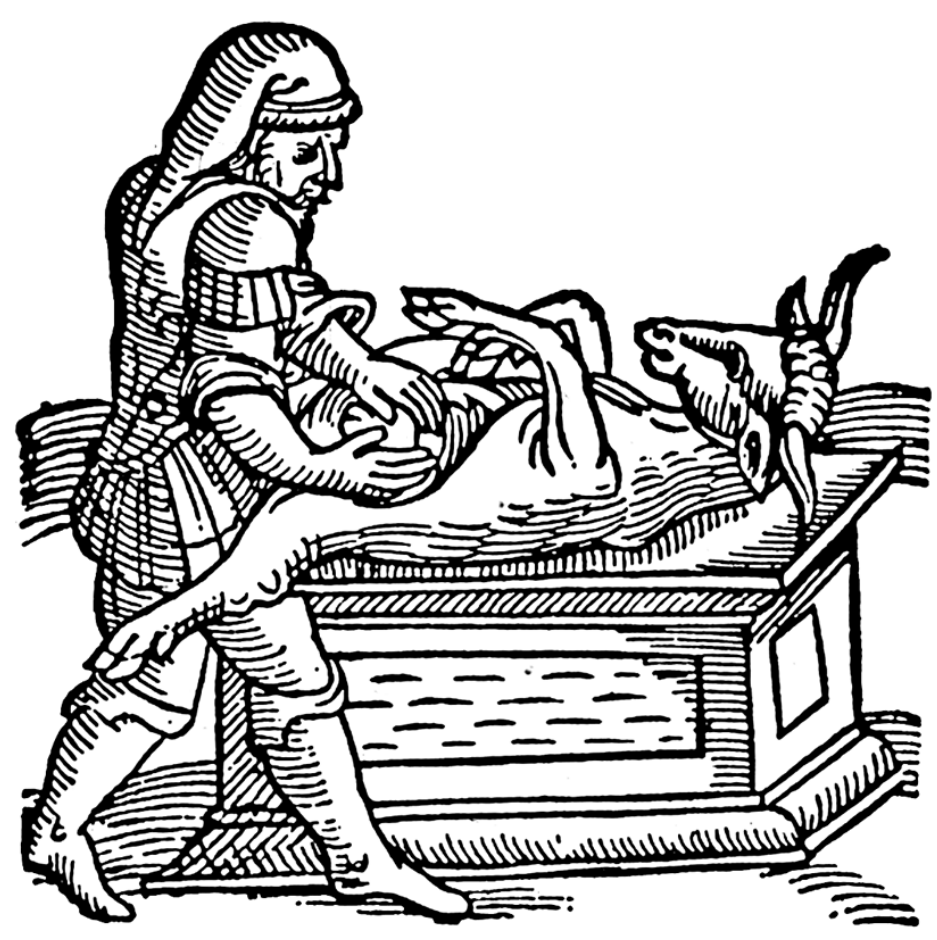

Fig. 1a. Hepatoscopia. Woodcut illustration from C. Lycosthenes 1557. 


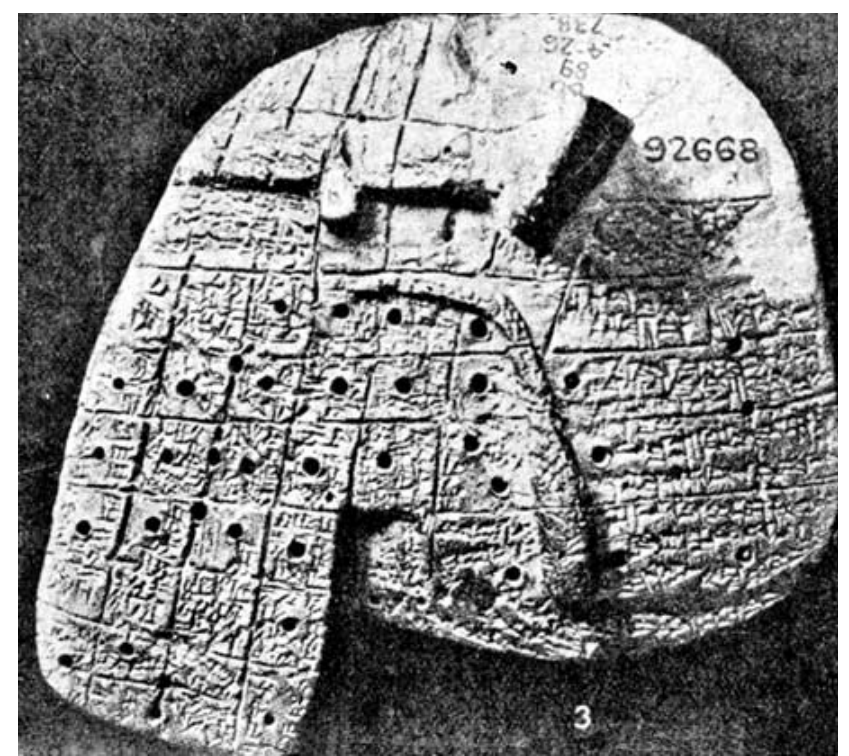

Fig. 1b. Liver of a sheep. Babylonian model of terracotta with inscriptions from $18^{\text {th }}$ to $19^{\text {th }}$ century B.C.

The first scientific dissections on animals and human bodies are dated back to the great Greek physicians. All members of this group lived during the last 400 years of Greek intellectual leaderschip and the first 200 years of Roman domination. One of them was Herophilos (325-255 B.C.), born in Chalderon, a small town on the Asiatic side of the Bosperus (now Turkey). He received his medical training

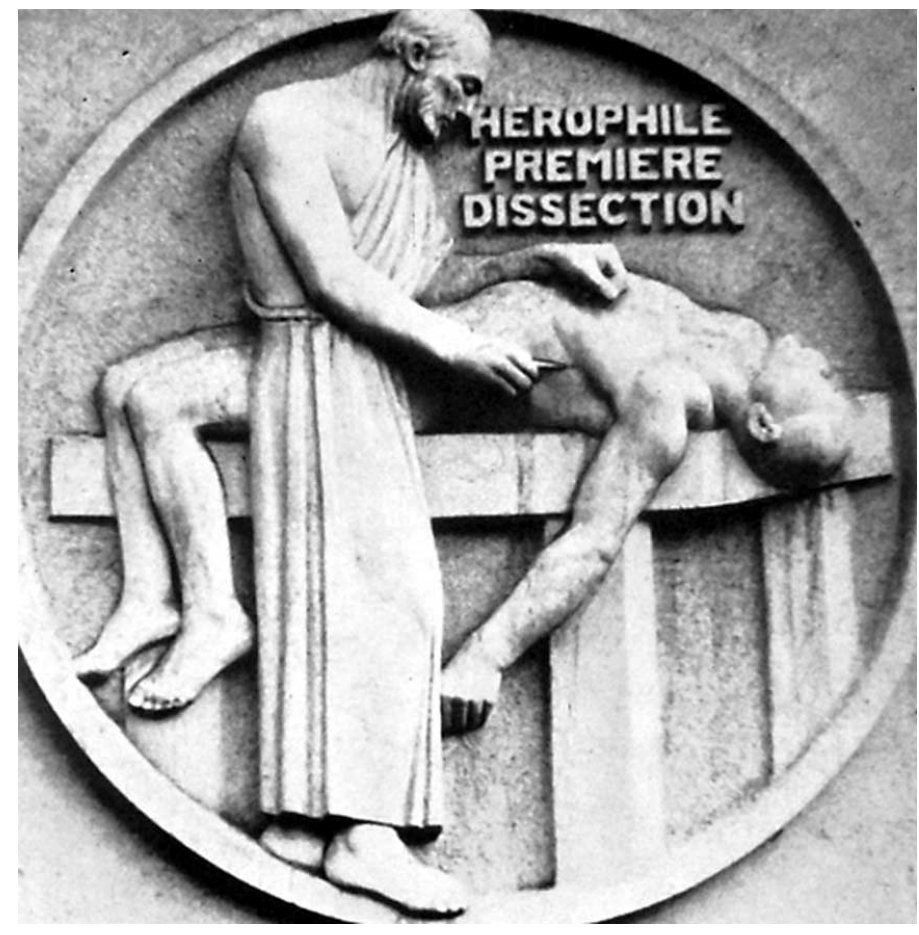

Fig. 2. Herophilos, the first dissection. Stone relief at the front of the main entrance of the Nouvelle Faculté de Medicine Paris (diameter 1,20 m), from P. F. Niclausse 1955. in Cos under Praxagoras, a famous physician and anatomist during the $4^{\text {th }}$ century B.C., who taught at the Hippocratean medical school on this island. After completing his education he moved to Alexandria in 300 B.C. to practice his profession. Together with his contemporary, Erasistratus (310-250 B.C.), he was the first to perform systematic dissection of the human body. Herophilos (Fig.2) was an adherent of the dogmatic doctrine, and Erasistratos was an empiricist (later Methodist). It was rumored down the centuries that they procured criminals out of prison by royal permission, and dissecting them alive. This period was limited to $30-40$ years, then scientific human dissection was forbidden. These two men made outstanding advances in anatomy and physiology; Herophilos is called the father of Anatomy, Erasistratos has been called the greatest physiologist of this era (Wiltse \& Pait 1998). The only person who might challenge Herophilos in this assessment is Vesalius (1514-1564) (Fig. 3). Unfortunately, all his original writings were lost. A great deal of his work did survive in the writings of Galen and in those of his students and later members of the Herophilean school. It is believed that most of Galen's knowledge of anatomy came from Herophilos, Galen never dissected a human cadaver. The last creative age of Greek medicine ended with Galen's death in 200. This became so parvaise, that for 1500 years to study medicine was to study Galen. With the fall of Rome the dark ages settled over Europe, medical lore survived in other parts of the world to flower again during the Renaissance.

Some extraordinary illustrations of human dissections arose during the $13^{\text {th }}$ century, mixed from reality and vivid imagination. Around the year 1237, Guillaume de Lorris wrote the famous Roman de la Rose, that contained more than 4050 verse at his death. It was Jean de Meun, who continued this poetry and added another 18000 verse. In long poems and fantastic drawings the authors put into words their impressions about human vivisections. Emperor Nero orders the dissection of his mother Agrippina to find out the localization where he derived from (Fig. 4a, $4 b)$. This medieval parchment manuscript, dating from the $14^{\text {th }}$ and $15^{\text {th }}$ century survived in numerous copies.

The dogmatic-scholastic ideology of the Middle Ages paralyzed the natural sciences to such an extend that no human dissection took place. But in the Dark Ages there was a famous medical school at Salermo, actually run by Jews, Christians and Arabs, but only one pig a year was dissected. It was thought that the pig's anatomy was similar to that of man. The $13^{\text {th }}$ century saw an awakening of social and intellectual life; many universities were founded, most of which had a medical school. Perhaps the foremost 


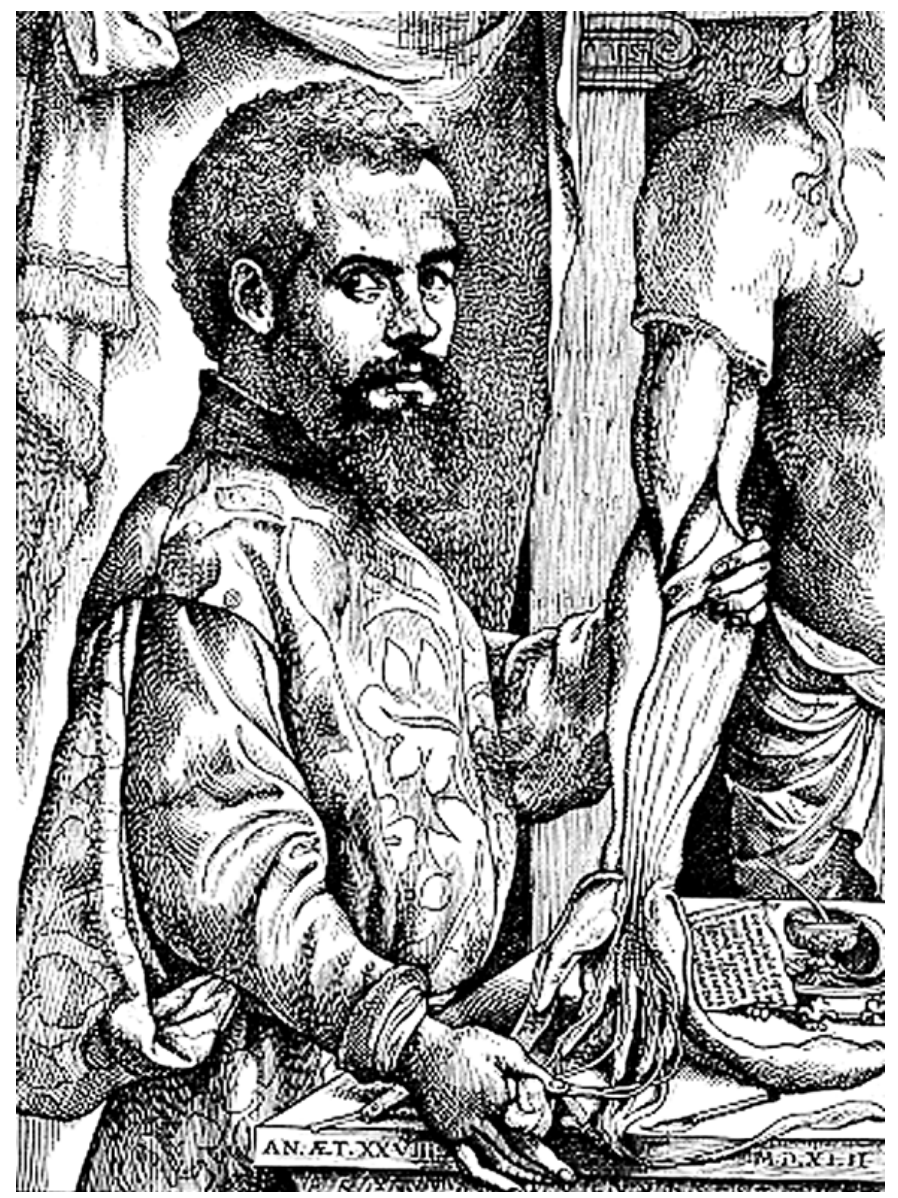

Fig. 3. Andreas Vesalius (1514-1564). Woodcut illustration from his book "De humani corporis fabrica", Basel 1543. Taken from R. N. Wegner 1917. of these was at Bologna, which began a Law School in 1000; medicine was added in 1156, but was controlled by lawyers until 1306. It is supposed that the first dissection was made in Bologna 1302 by Mondino de Luzzi (1270-1326), further dissections followed in Montpellier, Padua, Perugia, Prague, Venice, Firence, and Lerida. Mondino became so famous that students from all over Europe flocked to his lectures. His book "Anathomia" published 1316, remained a standard for 200 years. In this age of pilgrimages, students traveled all over Europe seeking the best teachers, who merely read from a Latin translation of an Arabic translation of Galen or Hippocrates and explained each paragraph to the students. According to the rarity of dissection during the $14^{\text {th }}$ and $15^{\text {th }}$ century, they were arranged in any provisional rooms (Figs. 5 and 6), and if not available even in the open air. No requirements for anatomical buildings arose at that time.

Another stimulus to anatomy came from the great Renaissance artists, who were no longer satisfied with stiff Byzantine portrayal of figures. Many famous artists of this period dissected themselves or drew dissections, among them were Verrocchio, Donatello, Mantegna, Raphael, Boticelli and Michelangelo. They cared nothing for Galen but relied on their own observation. The greatest was the inquisitive and brilliant Leonardo da Vinci, who is said to have dissected more than 30 bodies.
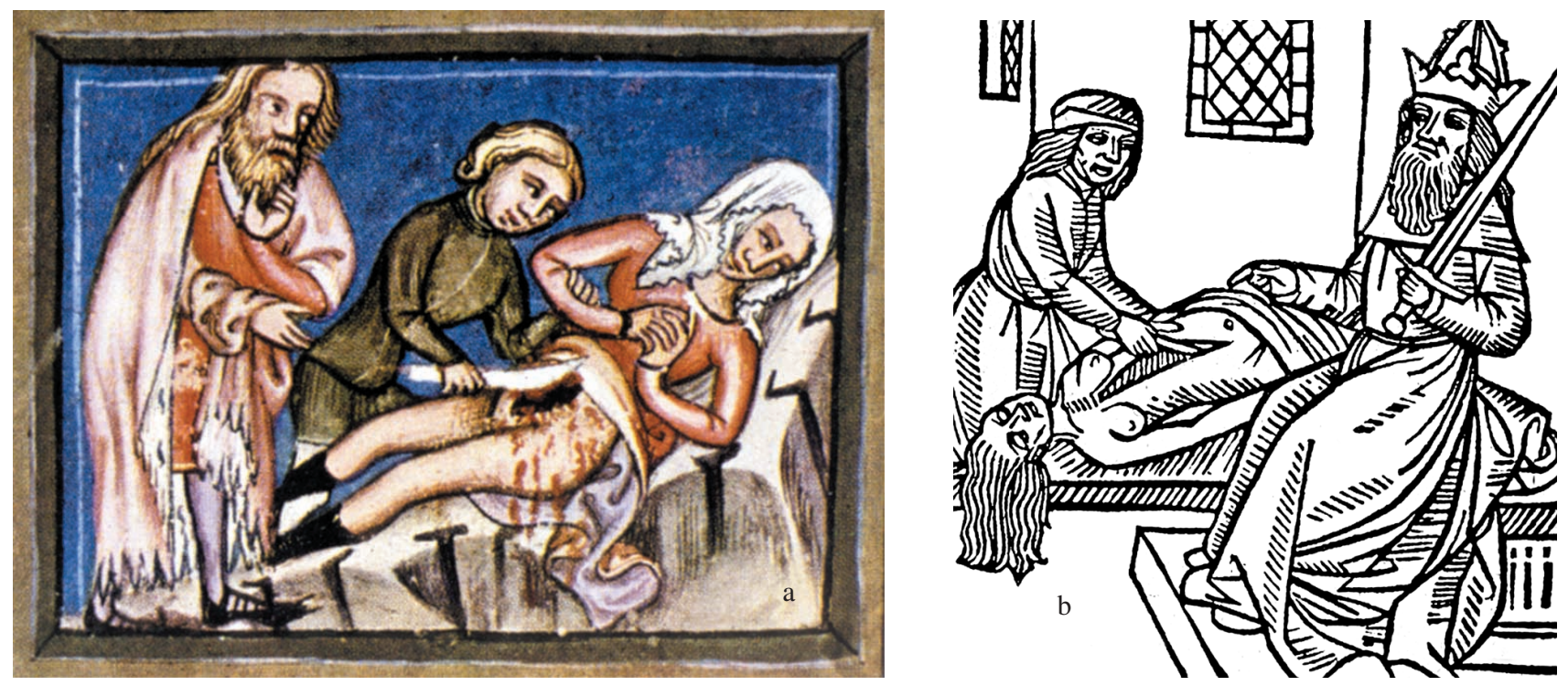

Fig. 4. Emperor Nero is watching the dissection of his mother Aggrippina. a. The wife lying on the bottom in light dress is still alive, the arms are bent by a rope. Colored ink drawing in: Jansen Enikel, Weltchronik, Bayrische Handschrift, ca. 1410, Heidelberg University Library. b. The wife is lying on a wooden table, Emperor Nero instead of his scepter a sword in his hand. Woodcut illustration. Paris, Guillaume de Lorris et Jean. D Meun,Paris Antoine Vérard 1494- 1495. 


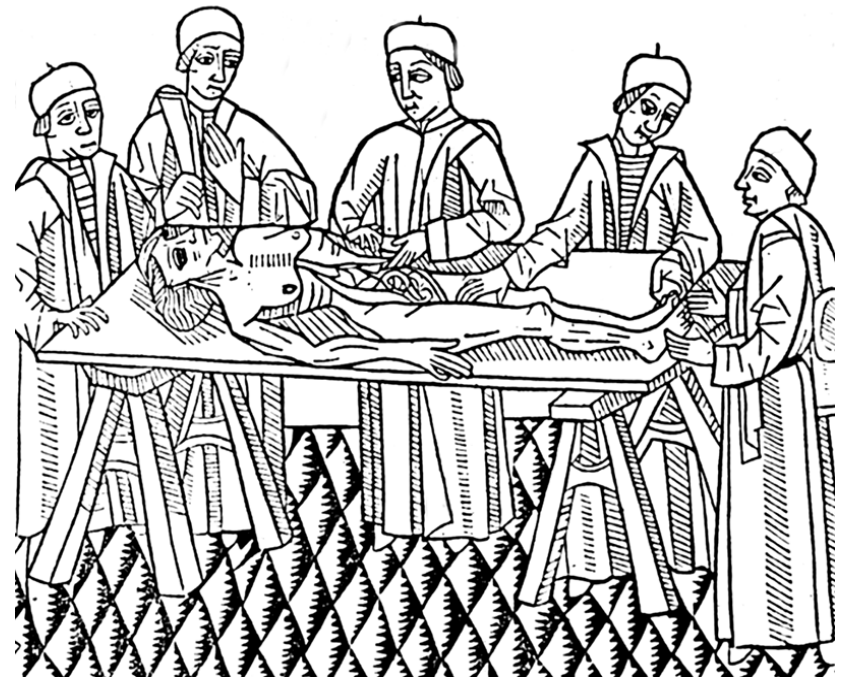

Fig. 5. Anatomical demonstration of an open human body, lying on a wooden table in a poor room. Woodcut illustration in Bartholomeus Anglicus, Lyon, 1485.

The new era of anatomy began with the great Belgian anatomist Andreas Vesalius (1514-1564), after studying in Paris, he came to Padua, the Republic of Venice, to teach anatomy and surgery. He did so well that a short time after receiving his doctorate he was made Professor of anatomy and surgery, at age of 24. Even Vesalius had problems, the antipathy toward human dissection became increasingly severe. It is said that on one occasion he left Paris and moved to Padua for fear of his life because of his human dissecting. His textbook "De humani corporis fabrica libri
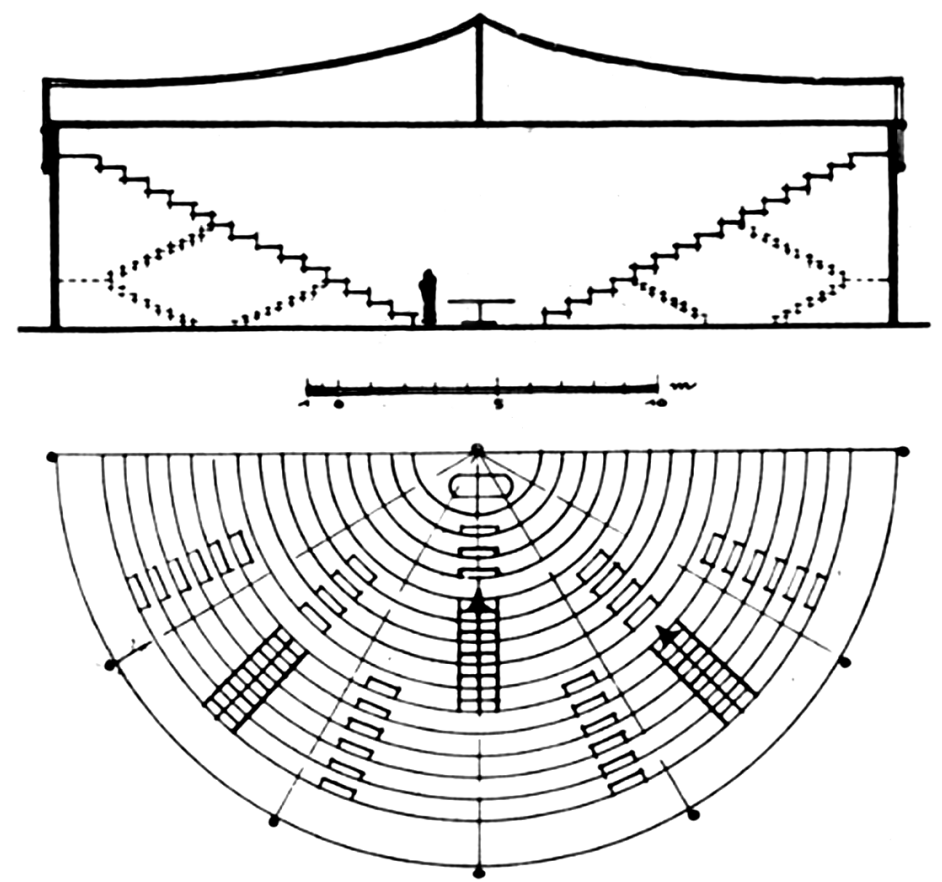

Fig. 7. Architectural design of an anatomical theatre from Carolus Stephanus. In his book "De dissectione partium corporis", Paris 1546.

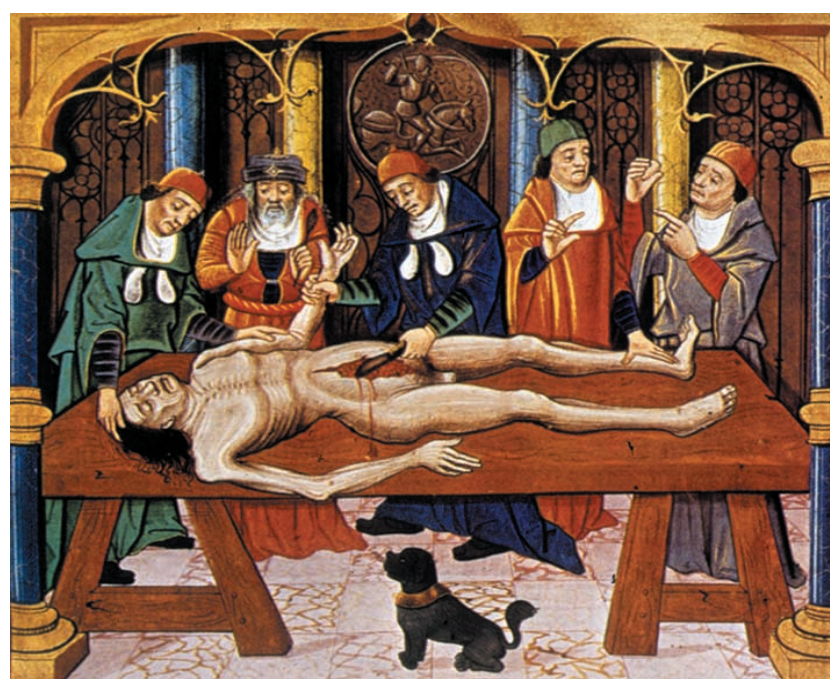

Fig. 6. Anatomical dissection in a magnificent hall, the background is decorated with gothic emblems and pillars. Miniature in Bartholomeus Anglicus (1485, Paris, Bibliothèque Nationale.

septem" that referred anatomical findings of human bodies became famous and overturned the theories of Galen. This remained the standard work for 200 years.

Early designs of Anatomical Theatres. The development of anatomical theatres is a part of academic history for nearly 600 years. Anatomical dissections of human bodies required a special auditory, this gave rise to the history of the theatrum anatomicum. The first model of a special auditory for dissection was taken from the ancient amphitheatres in Rome and Verona. The first design of an anatomical auditory, which pointed the way to the future was prepared by the anatomist Alexander Benedictus from Padua 1497. He suggested:

- a large auditory for an adequate number of visitors,

- good visibility for the visitors,

- a well illuminated dissection table in the center of the auditory,

- sufficient ventilation,

- two guards for protection against unwanted persons,

the collection of an admission fee.

Another architectural idea came from Carolus Stephanus. He described a wooden building with a capacity of 500 seats and covered by a tend roof (Fig. 7 ). Although the size of this anatomical theatre was a pure illusion the semicircular arrangement of the seats became very common in the $19^{\text {th }}$ century. 

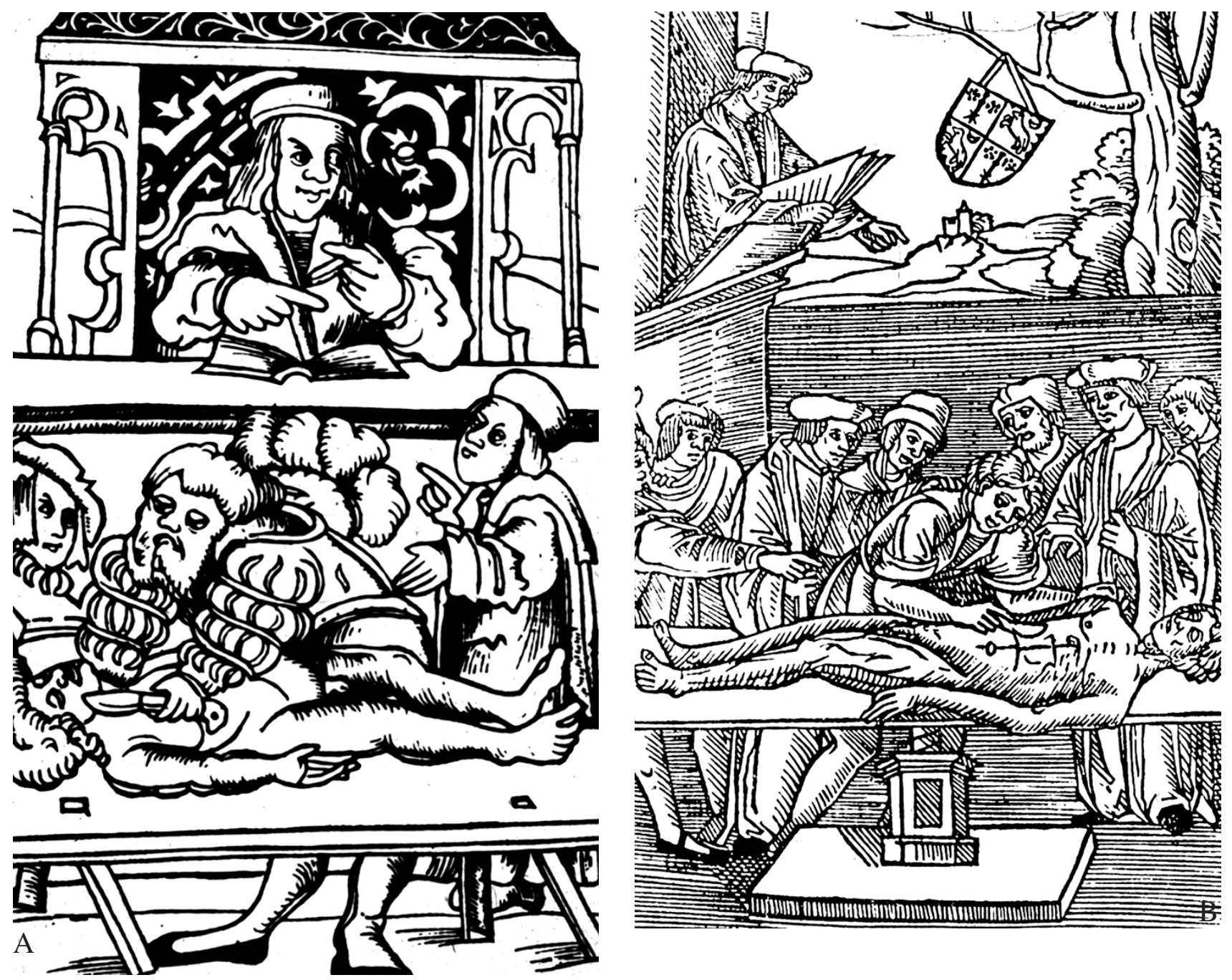

Fig. 8. Theatrum anatomicum temporarium. a. Woodcut illustration of the book Anatomia Mundini, Rostock, University Library ed. 1513. in G. H. Schumacher and H.-G. Wischhusen 1970. b. Woodcut illustration, Anatomie de Mondin Paris, A. Lotrian et D. Janot 1532.

Theatrum Anatomicum Temporarium. By the $16^{\text {th }}$ century anatomy had become a very popular subject, not only with students but with the general public. It was in Italy where the first temporary buildings were erected. Dissections became public performances with a strict ritual. Temporary anatomical theatres were used for demonstrations and dismantled each year after the dissection was over. Founded on the ideas of Benedictus and influenced from the ancient amphitheatres in Rome and Verona, the name Theatrum Anatomicum was created.

This was a wooden construction which might be comparable with a kiosk (Fig. 8a, 8b). It should be a sizeable and well-ventilated place with seats all around it, and of such a size as to hold a great number of spectators, so that the dissectors shall not be disturbed by the crowd. Seating should be allotted in order of rank. There must be an usher to keep an eye on everything and to put people in their places, as well as guards to restrain the eager public as it enters. Two reliable stewards should be chosen to make the necessary payments from the money that was taken. Torches were ordered, because the body must be in sufficient light.

Examples of the dissection in a temporary anatomical theatre are given by illustrations in the textbooks of Mondino de Luzzi. In more than 40 editions it was the guiding textbook of anatomy during some centuries for many Universities in Europe. The designs of his illustrations are as follows (Figs. $8 a$ and $8 b)$.

The Professor presides at the top teaching from the book from Galen,

stars in the background are symbolizing the high prestige of the Professor, 


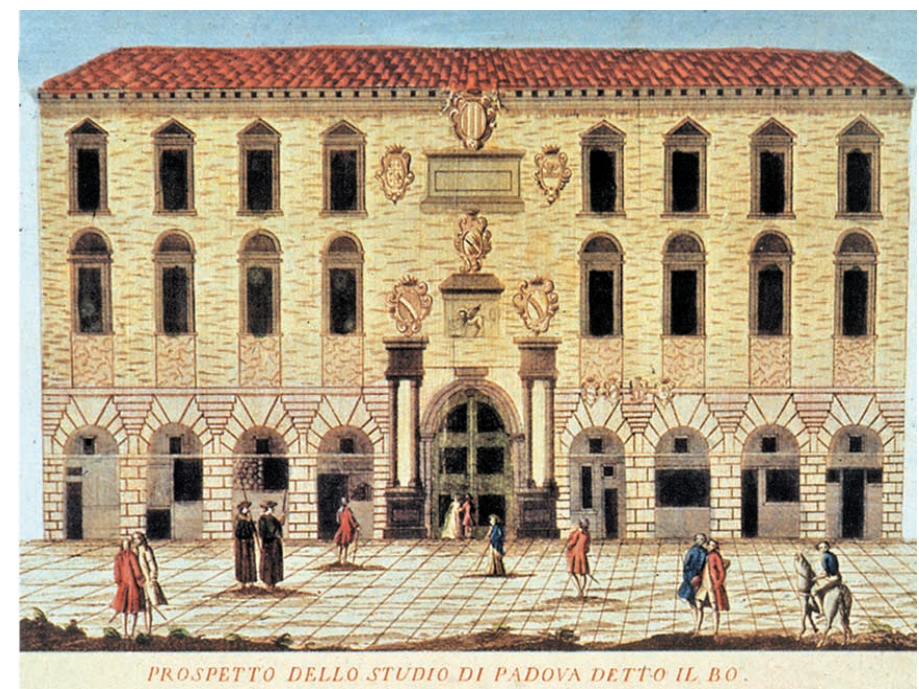

Fig. 9. Main building of the University of Padua.

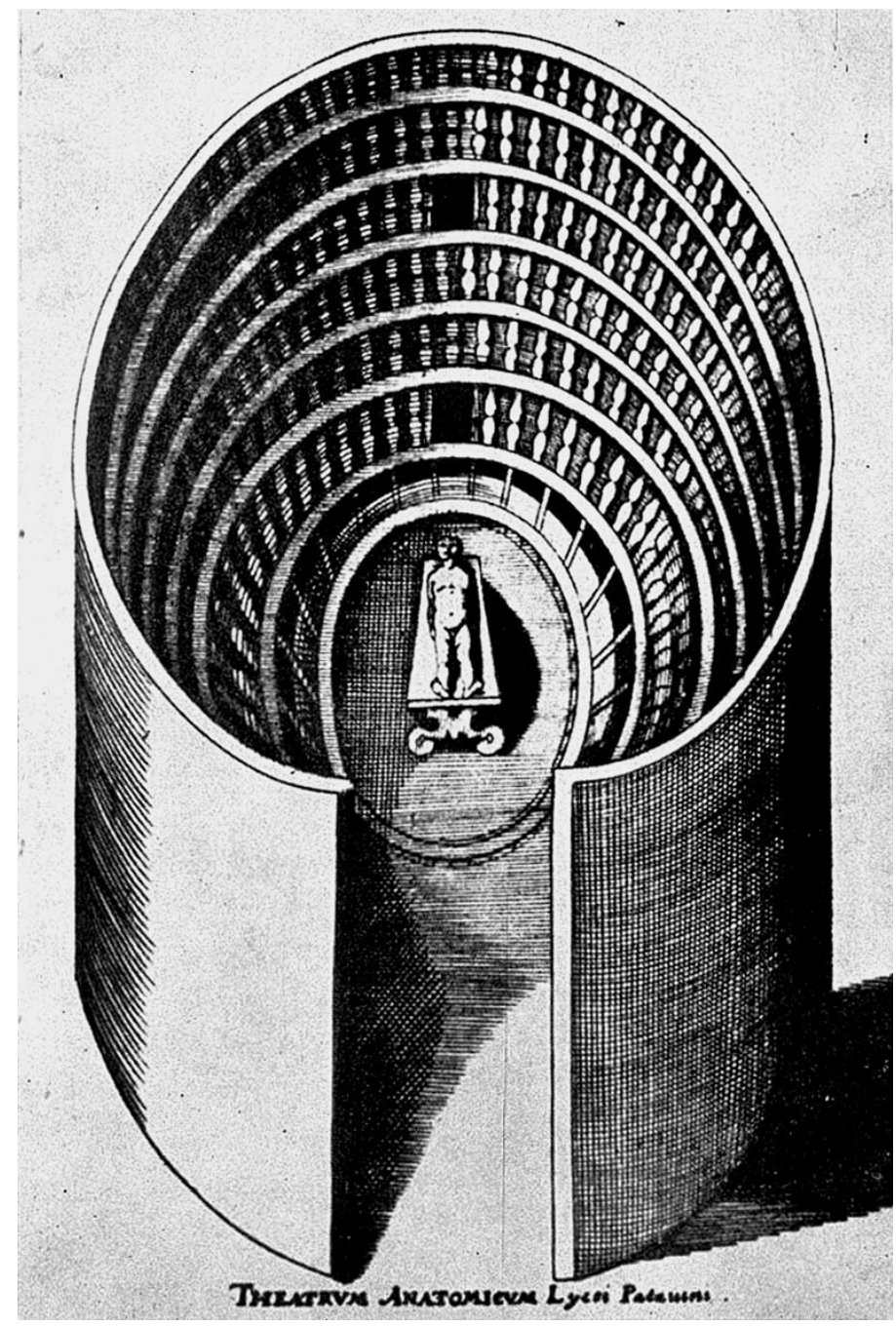

Fig.10a. Theatrum anatomicum Lycei Patavini, a. Copperplate engraving in: J. Ph. Tomasini, Gymnasium Patavium, Undine 1654. the windows are open, the landscape is in view; this may stand for ventilation because conservation were unknown at that time,

next step down, the Docent is transmitting the findings of the dissection to the Professor and his interpretations to the students,

at the bottom lies the cadaver on a simple table, dissected by a barber and at the side are the students.

Theatrum Anatomicum Permanentum. The second half ot the 16th century was a time of exploration. A new continent was discovered, Drake made the first world tour, Galileo explored the universe and Luther shattered religious tradition. Progress in anatomy gave rise to establish permanent anatomical theatres. Two types of different designs became famous in the $16^{\text {th }}$ and $17^{\text {th }}$ century, the Padua type and the Bologna type. Both of them were of wooden construction incorporated into a tall building of the University, but with different architectural characteristics.

The Padua type started in Padua (1594), where anatomy had a high reputation at that time. It was a practical-scientific type, designed by Fabricius ab Aquapendente (1537-1617) that served as a model for many anatomical buildings e. g. in Leiden (1597), Groningen (1654/5), Kopenhagen (1640/3), Upsala (1662), Amsterdam (1691), Altdorf (1650), Halle (1727) and Berlin (1720). The permanent anatomical theatre of Padua, was of wooden construction, incorporated into a palace in which the University was housed (Fig. 9). This had been used for 278 years before it became a museum in 1872 .

The architectural characteristics of the funnel shaped auditory are as follows: Size $8.75 \times 10.0 \mathrm{~m}$, height $12.0 \mathrm{~m}$, equipped with six concentric steep ascending rows around it, $0.92 \mathrm{~m}$ in height each (Figs. $10 \mathrm{a}$ and 10b). Each gallery is guarded by a carved balustrade similar to those around alpine houses. There are no seats; even dukes and philosophers had to stand for hours, and they had to be slim to squeeze in at all. The theatre had a capacity for 200 visitors. Deep down in the well stands the section table over a trapdoor through which it could be lowered necessary to hide the corpse quickly. The professor's chair almost touches the table and there is little room for assistants and the eight students who held the candles. On the front row stood the rector of the school, professors, Venetian nobles, councilors of the nations and the members of the medical college. The second and third rows were reserved for students and the rest were open to public. 
So many great men worked here that this theatre indeed became a shrine of anatomy.

But the funnel shaped construction had some unfavorable side effects:

The devoid of daylight required artificial illumination with candles or torch,

the narrow rows of chairs were inconvenient for passages in the auditorium,

the place for dissection and demonstration suffered from the limited space,

the extreme height of ascending chairs required an adequate tall building, which was very rare in the universities at those days.

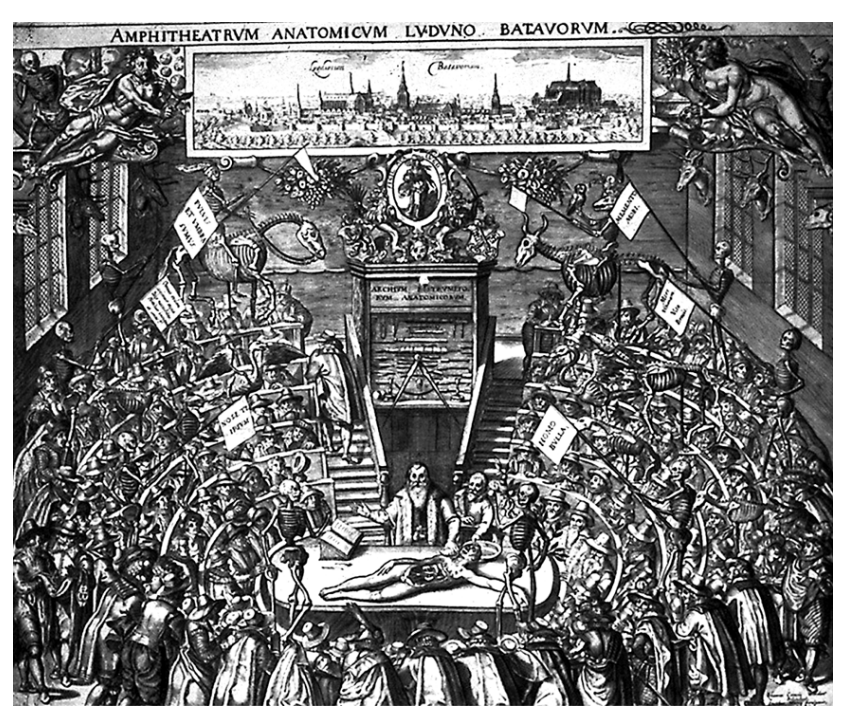

Fig. 11. Theatrum anatomicum in Leiden. Anatomical lecture at the time of Peter Pauw. Copperplate engraving, probably 1615. in: G. Wolf -Heidegger and A. M. Cetto. Basel 1967.

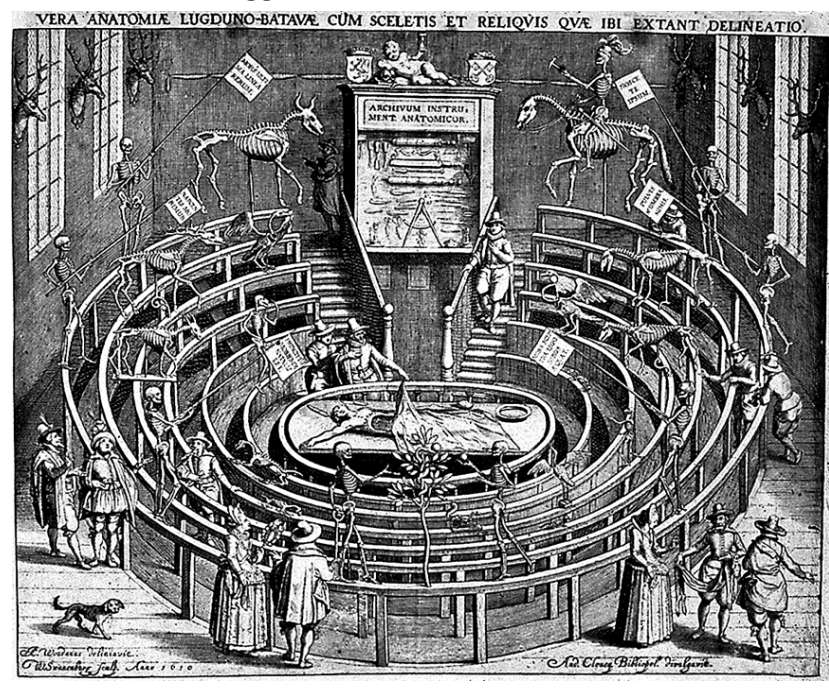

Fig.12.Theatrum anatomicum in Leiden as a museum. Copperplate engraving 1612. Leiden, Leidse Prentenverzameling, gemee-Archief.

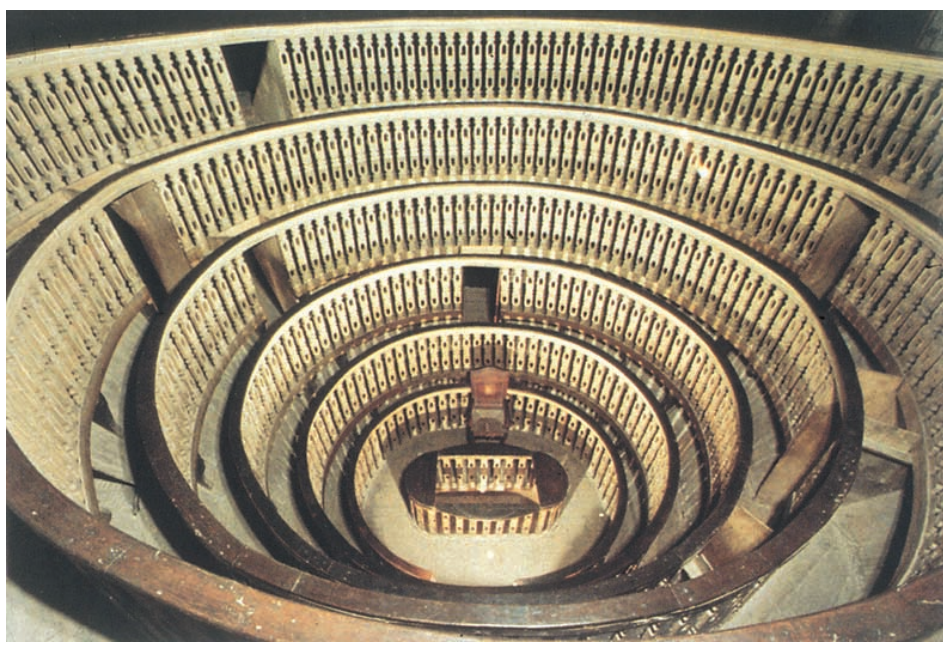

Fig. 10b. Theatrum amatomicum of Padua, bird's-eye view.

Anatomical theatre in Leiden. This was a more favorable construction, designed by Peter Paaw and opened in 1597. Peter Paaw got his doctorate in Rostock in 1587 and was called to Leiden as Professor of Anatomy in 1597. The auditory was equipped with 6 wide flat ascending rows of seats, so that the large windows remained uncovered and daylight could flow in for illumination (Fig.11). Whenever the dissection was finished the auditory was changed to an attractive museum (Fig. 12 ). This type was widely imitated e.g. in Groningen (1654/55) and Kiel (1666) as well as in some Universities of the Northern Countries.

A mediator between Leiden and the Northern Countries was the anatomist Simon Paulli, born in Rostock and elected as Professor of Medicine (1603) in Rostock. He designed the "Domus anatomica " in Kopenhagen (16401643) after the model of Leiden, where he had started his career. It is reported that the auditory was equipped with a rotating dissection table, which made it possible to turn the tabletop towards the position of the sunrays (Fig. 13 ).

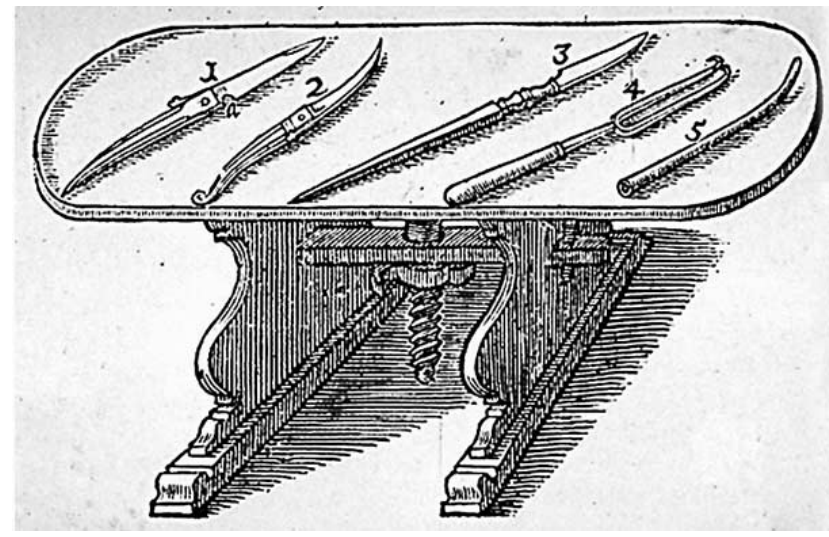

Fig.13.Rotating table with ancient instruments used for anatomical dissections. Michaelis Lyseri, Culter anatomicus. Kopenhagen 1665 , pp. $5 / 6$. 
Theatrum anatomicum in Uppsala. This should be mentioned as an extraordinary anatomical theatre on the top of the university main building, named the Gustavianum (Fig.14a). It was erected 1620, but the feature which made it

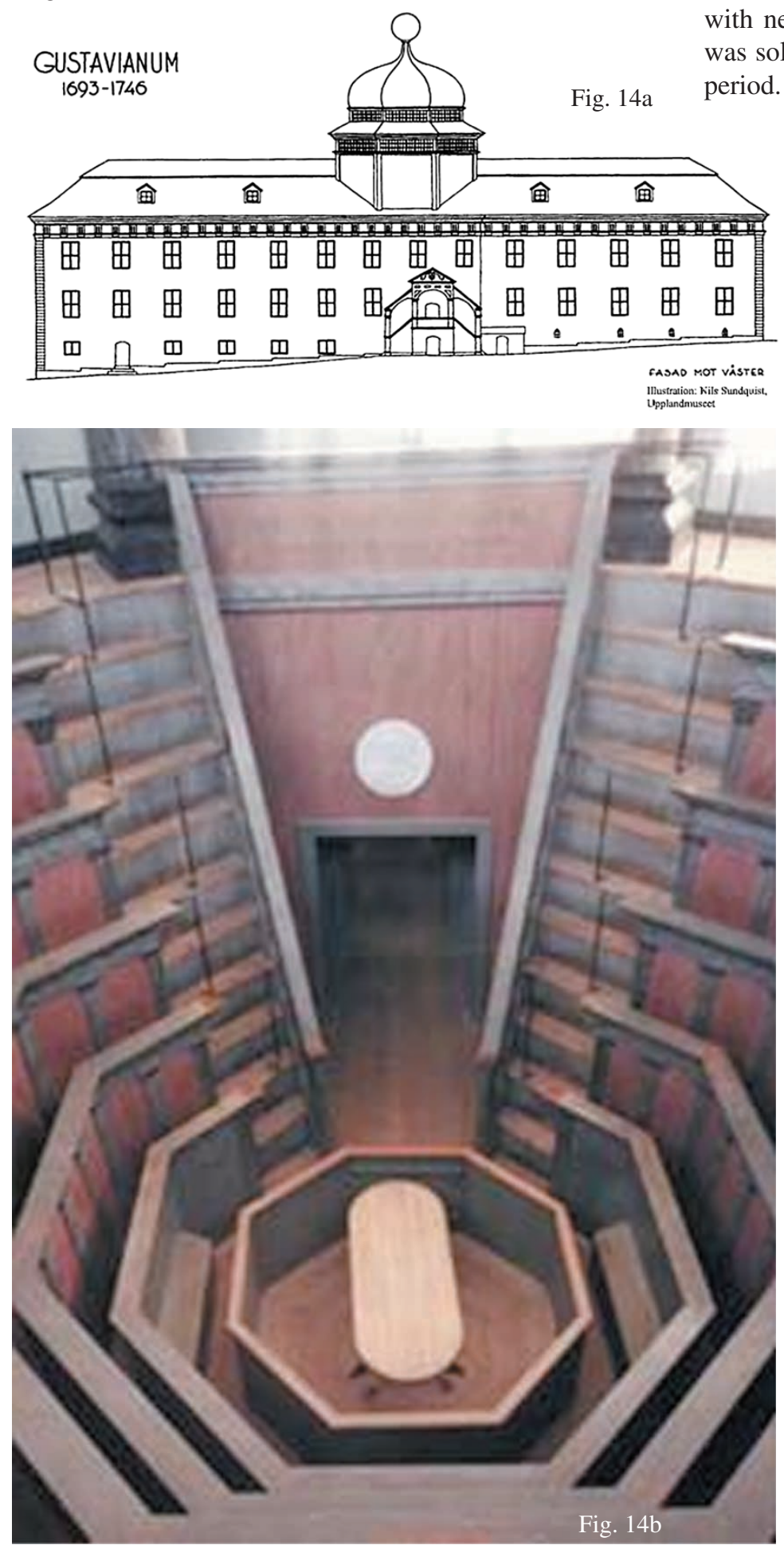

Fig.14. a.University Building "Gustavianum" in Uppsala with the Theatrum anatomicum at the top of the roof. b. The interior of the anatomical theatre in Uppsala. so distinctive, was the copula of this building with the sundial/ sun globe, established in 1662. The copula on the top of the domed roof of the Gustavianum was a new creation, beaming down through the windows provided the anatomical theatre with necessary lightning and the problem of illumination was solved. This was the most progressive solution in this period. The interior of the Theatrum anatomicum was tunnel shaped, similar to the Padua type (Fig. 14b). The room looked like a temple, the glory of God was to be revealed in the many way in which he was created the human body.

The Bologna type started in Bologna (1649), the design is not comparable to the Padua type, because of its own history. Around the $16^{\text {th }}$ century public dissection became popular in Bologna, especially during the carnival season (Fig. 15). This gave rise for a representative rectangular auditory similar to a medieval meeting place, decorated with beautiful panel boards and sculptures of two musclemen supporting the canopy (Fig. 16). This theatre was in use till for 154 years before it became a museum in 1803. During World War (II) it was damaged, but after restoration it is open for visitors. The only similar construction of this representative type was known from Ferrara in 1731.

Theatrum Anatomicum Solitarium. The 18th century brought heavily modifications on the structures of anatomical buildings, caused by the progress in morphological findings and the increasing number of students. Pioneer on the way to new architectures was the Anatomical theatre of the Academy of Surgeon in Paris, being established 1694 (Fig. 17). Based on the antic amphitheatre the building looked like a protestant church. Common to both of them was the capacity for many visitors around a central point, best visibility and optimal acoustic for a great number of visitors.

Le Grand Amphithéatre des Ecoles de Chirurgie in Paris, being erected in 1768-1775, might be an other example as an theatrum anatomicum solitarium (Fig. 18). The design derived from the roman Pantheon although the rows of the seats are arranged in a semicircle. The capacity of more than 1400 visitors, the arched ceiling and the source of light in the zenith met most of the expectations of an anatomical auditory at that time. But in this 


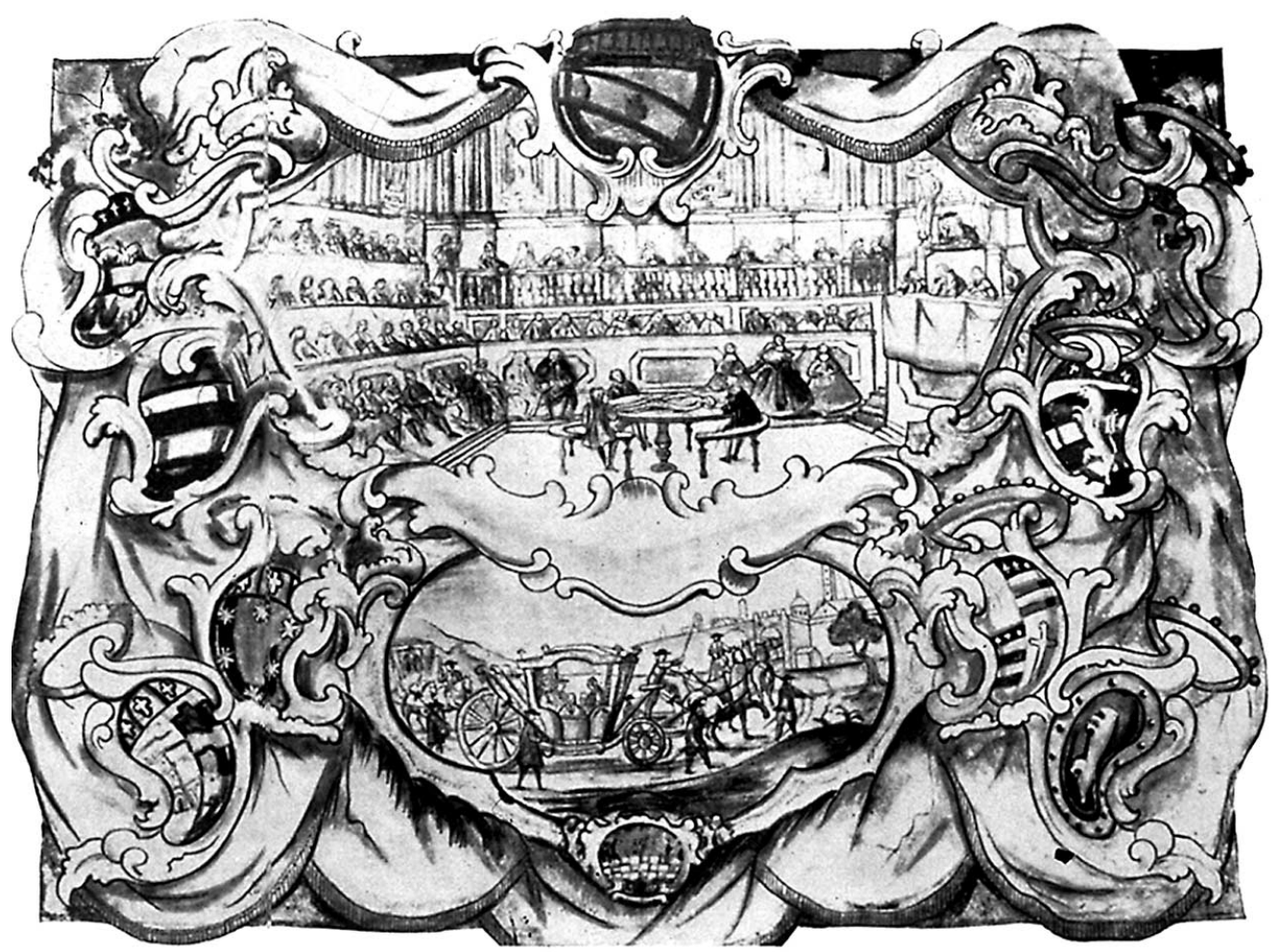

Fig. 15. Public dissection in the Theatrum anatomicum of Bologna. Miniatur from Bernadino Sconzani 1734. Bologna, Archivo dell Stato. In G.-H. Schumacher and H.-G. Wischhusen.

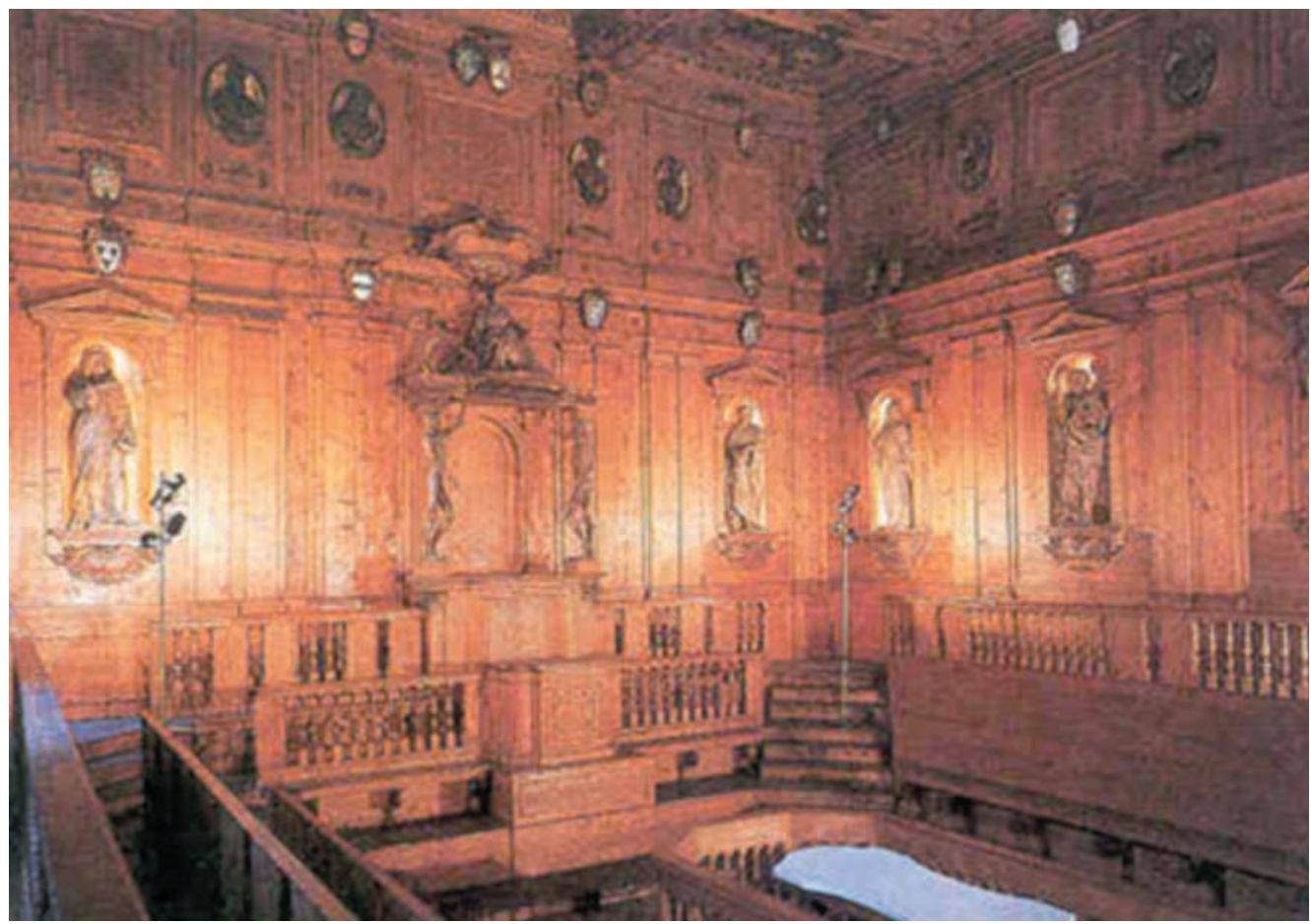

Fig. 16. Interior of the right angled theatrum anatomicum of Bologna.

gigantic frame the body on the table and the demonstrating Professor behind on a chair appear extremely reduced in size. It's hard to believe that an anatomical theatre with such great capacity was built already 200 years ago. Up today the Faculté de Médicine may be proud using the anatomical theatre as assembling hall. 


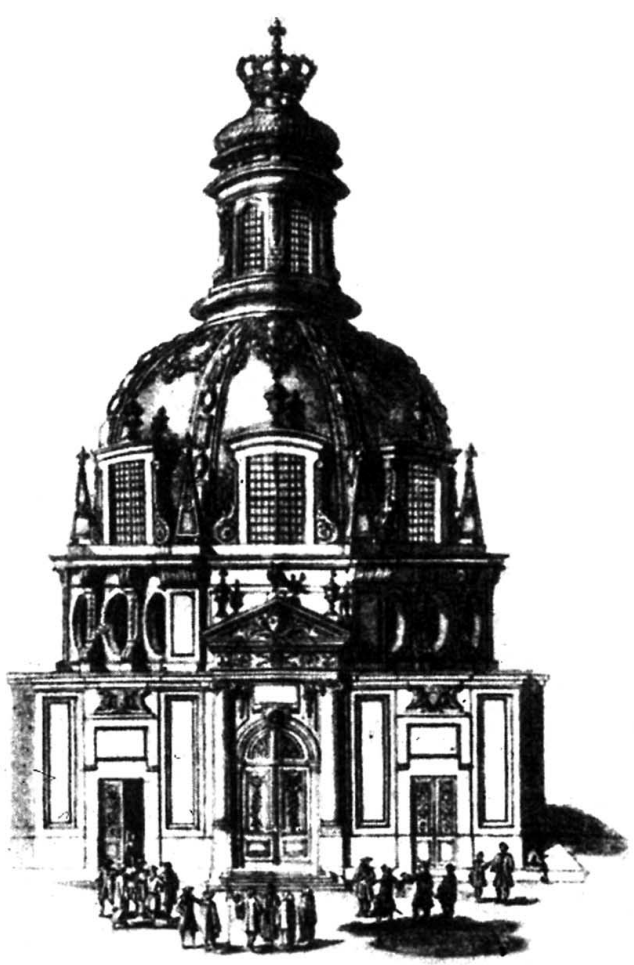

Fig.17. Theatrum anatomicum solitarium, Academy of Sergeon Paris 1694. after G. Wolf-Heidegger and A. M. Cetto. 1967.

Institutes of Anatomy. Conservation methods of human bodies opened a new era in anatomy. Dissections were not limited to a few days, its prolongation gave the opportunity for their integration into the curriculum and for the arrangement of anatomical collections. The accumulation of anatomical knowledge required different additional rooms for storage of the cadavers, preparation, maceration, research and exhibition. All these demands diminished the importance of the traditional theatrum anatomicum and gave birth to the foundation of anatomical institutes.

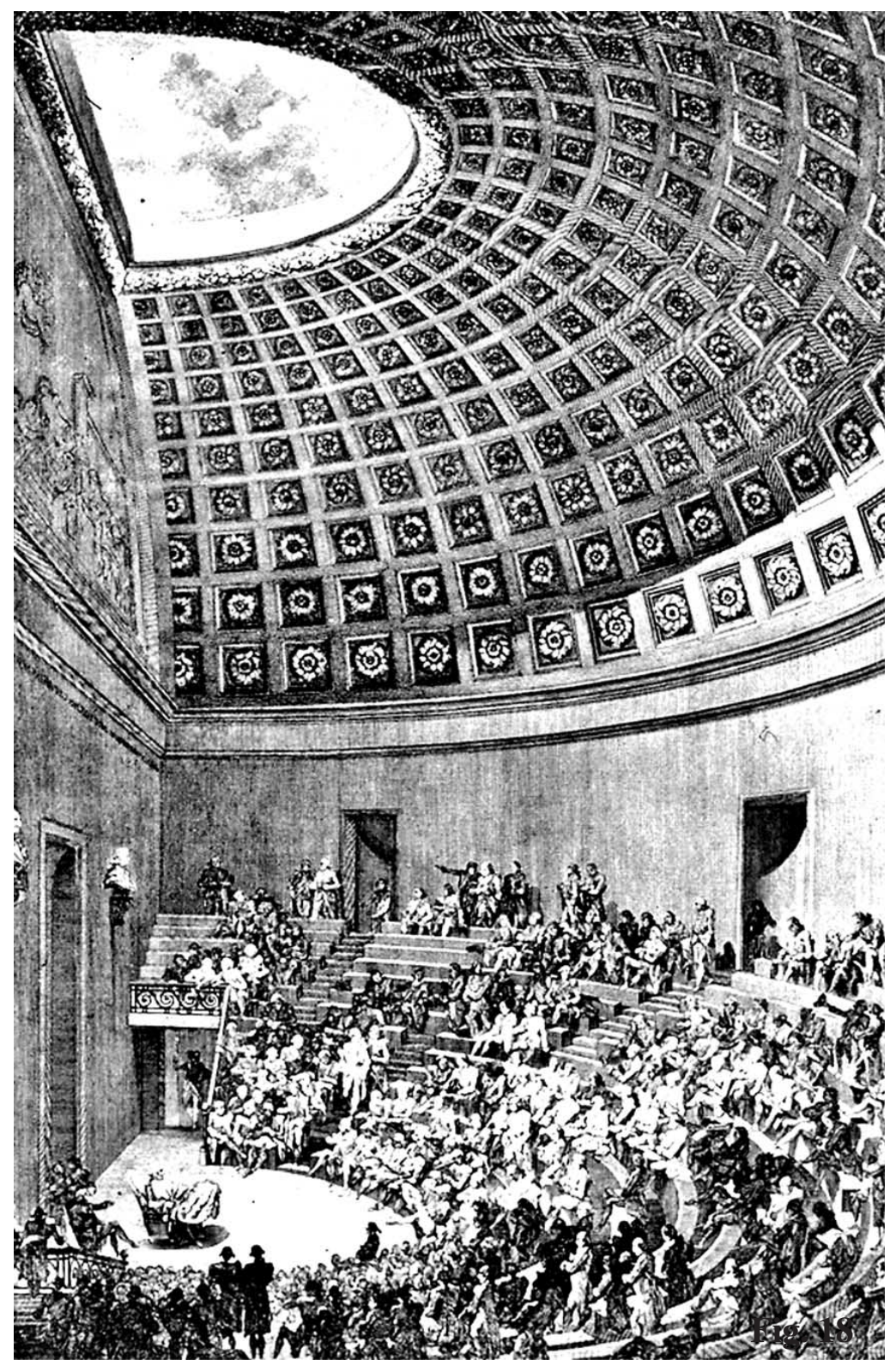

Fig. 18. Le Grand Amphithéatre des Ecoles de Chirugie Paris. Cupperplate engraving from Claude-René-Gabriel Poulleau, in: Gondoin, Description des Ecoles de Chirurgie, Paris 1780.
Anatomical Buildings (1770-1830) arose in different architecture and spread out widely, common to them was the separation of teaching era and rooms for laboratory work. In contrast to the architecture of the anatomical theatre in Paris was the strong symmetric Senckenberg Type, and the rectangular Sömmering Type.

The Senckenberg type developed in Frankfurt/ Main, where the Senckenberg Institute of Anatomy was built (1768-1776). The naming "Senckenberg" came from its Sponsor. It was a stretched building with central located auditory, bordered from two winged buildings on both sides, which contained rooms for preparation, maceration, a fountain and others (Figs.19a and 19b). The Senckenberg Institute of Anatomy was in use till 1908, it served as the model for Dorpat 1827 and Erlangen 1826/27.

Institute of Anatomy in Dorpat started with the rotunda 1803/5 and continued with the wing buildings, which were finished in 1825/27. The arched shape of this building was caused by the limited space on the cathedral hill (Fig. 20a) The rotunda contained the auditory with seats arranged in a circle (Fig. 21 ). The University of Dorpat, being established by the King of Sweden 1632, reestablished by 

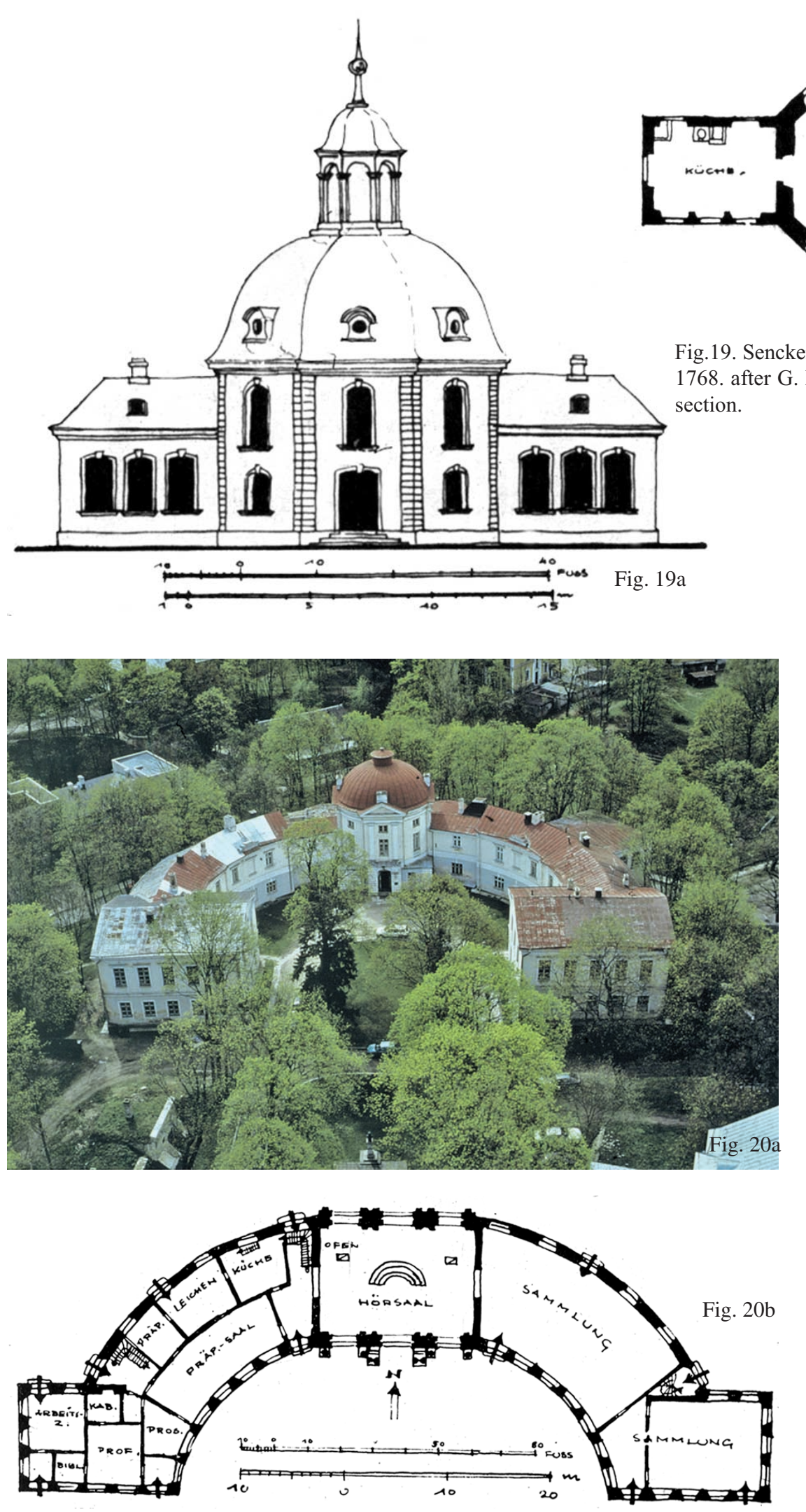

Fig. 20. Institute of anatomy, Dorpat 1827, a. Bird's eye - view, b. horizontal section of the anatomical institute Erlangen 1827, after G. Richter 1936.
Alexander I of Russia 1802, was the only German language University in the Russian Empire during the $19^{\text {th }}$ century, before Estonia became independent.

The Sömmering type, created by the anatomist Sömmering, gave new inspirations for further designs (Aumüller, 1970). This type was a solitary rectangular building with an extended auditory in the front, equipped with semicircular rows of seats, that reminded to the design of Stephanus (Figs. 22a and 22b). The extension of the auditory had a positive effect on lightening and ventilation. In contrast to the Senckenberg type, where the long wings were a burden for communication and transfer between the rooms, it was a very privileged functional construction. Sömmering's ideas affected the anatomical institutes such as in Munich 1826, Göttingen $1828 / 29$ and Greifswald 1854/55.

Anatomical Buildings from 1830 up to Now. Progress of natural sciences in the $19^{\text {th }}$ century necessitated adequate solutions for highest functional and architectural perfections. Common to all of them was the strict separation between the anatomical lecture hall and the halls for dissection, histology and museum (Figs. 23, 24, 26b and 29). In contrast 


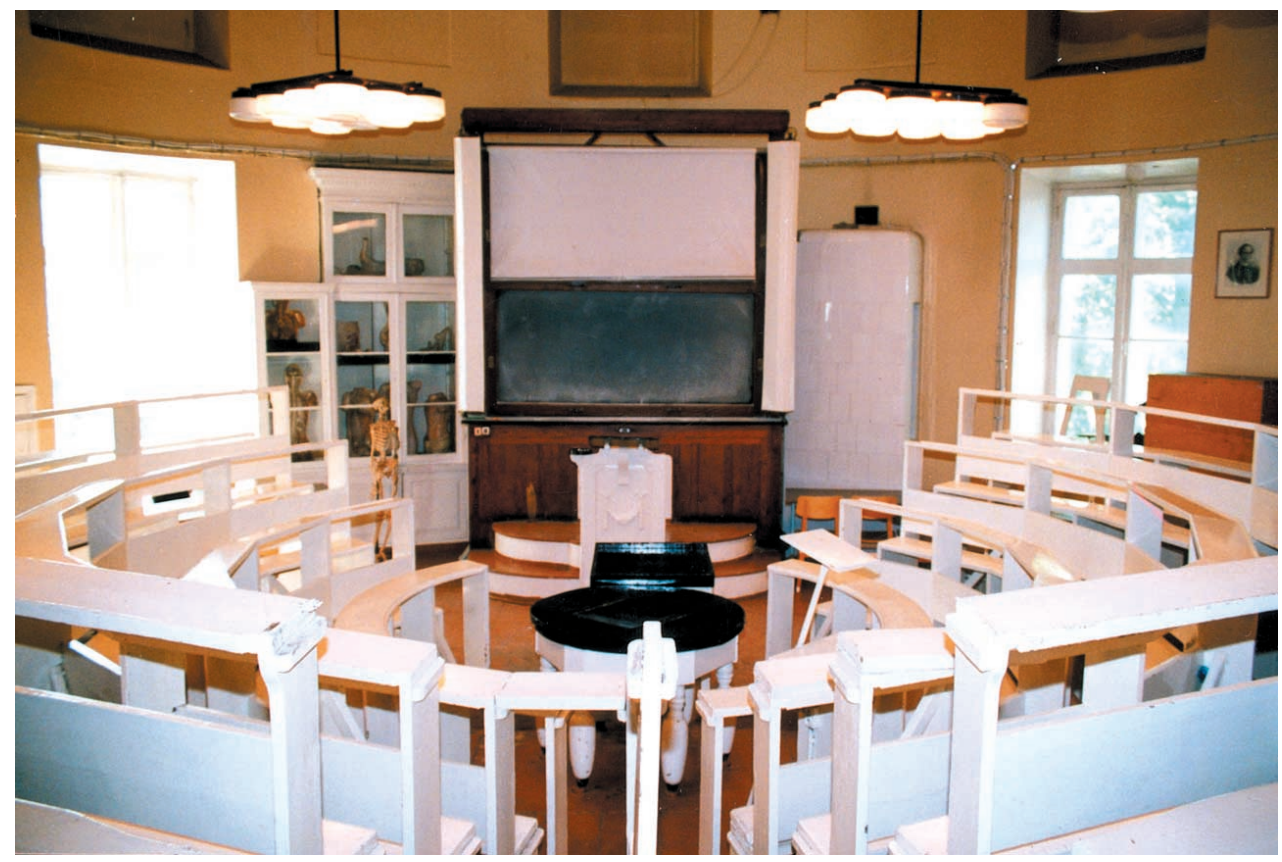

Fig. 21. Lecture hall of the Institute of Dorpat, 2005.

to the simple anatomical buildings of the past, modern institutes of anatomy grew up to giant organisms. Many different designs arose, which could be divided into two groups, the modern axial type, also called the GermanEuropean Type and the grouped type, also known as AngloSaxon-American Type (Fig. 25a, 25b).

The German-European Type of the $19^{\text {th }}$ century was the modern axial type. Mainly restricted to Germany and

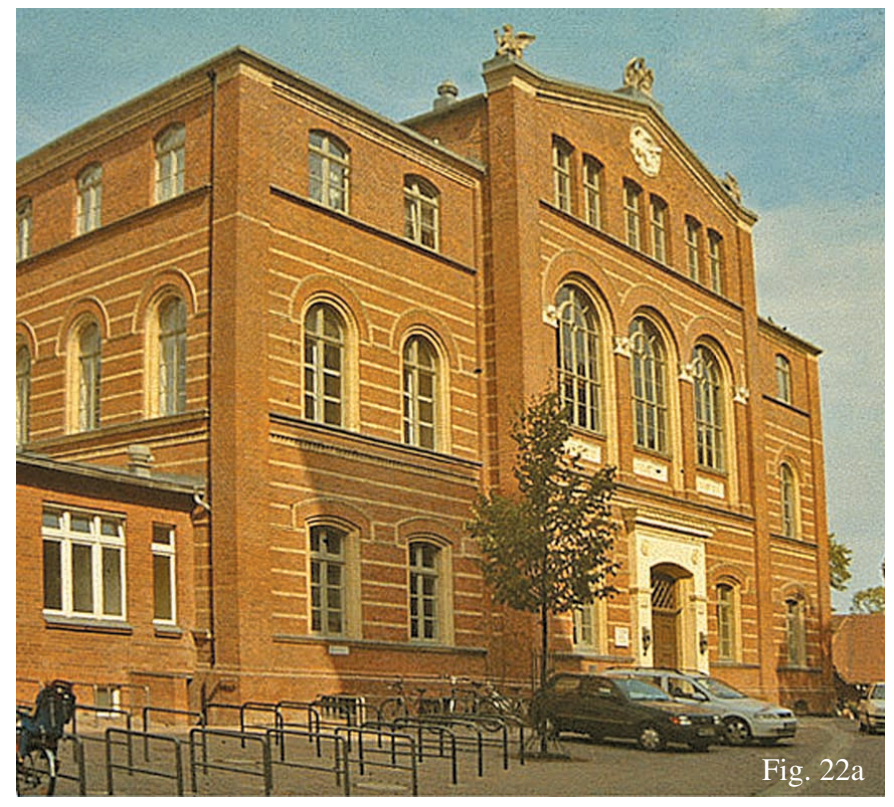

to the neighboring countries it became known the German-European type. It had a continuous passage between the lateral ends, that achieved quite a lot for communication between the rooms on both sides. The main idea was a functional localization of rooms and the improvement of unhygienic condition, e. g. the separation of all rooms with bad smell, such as the dissection hall and maceration. For its realization three demands were requested: 1 . perfect lighting, 2. complete ventilation and 3. maximal cleanliness. Some of the most important anatomical buildings of this type were established in Zürich 1842 , Berlin 1863-65, Freiburg 1867, Bonn 1872, Prague 1876, Rostock 1876-78, Strasbourg 1877 and Sofia 1929 (Figs. $25 \mathrm{a}$ and 26a).

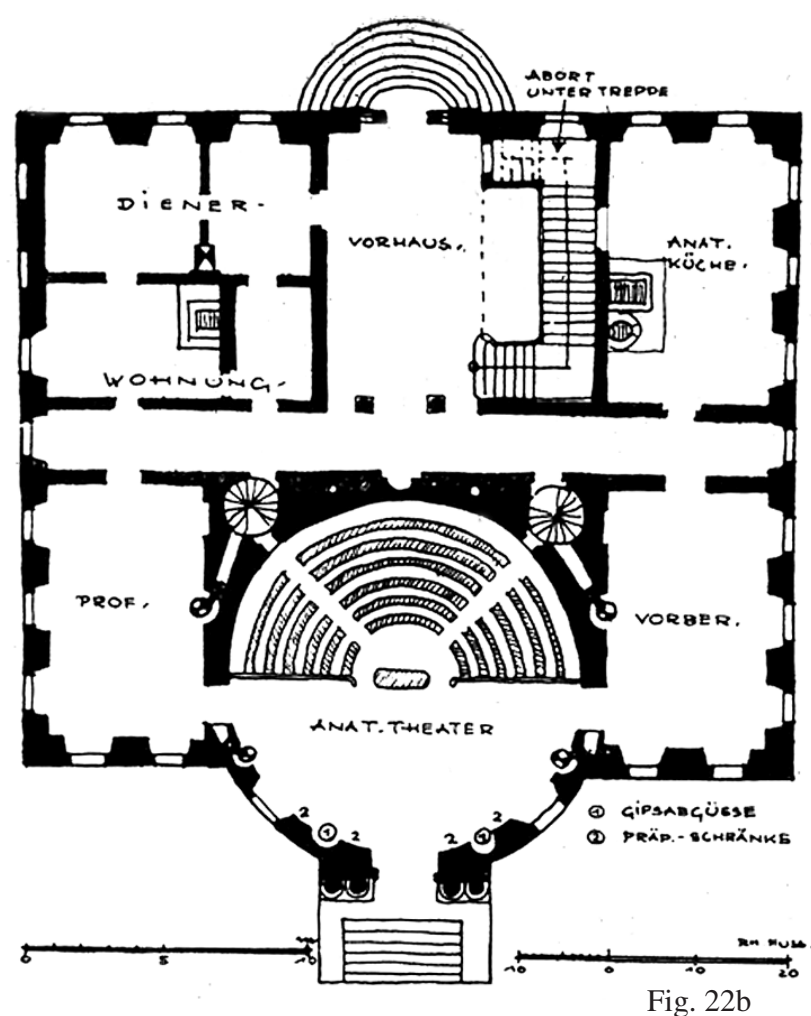

Fig. 22b

Fig. 22. Sömmering Type. a. Institute of anatomy, University of Greifswald 1854/55, b. horizontal section, Institute of Anatomy, Mainz 1787, after G. Aumüller 1970. 


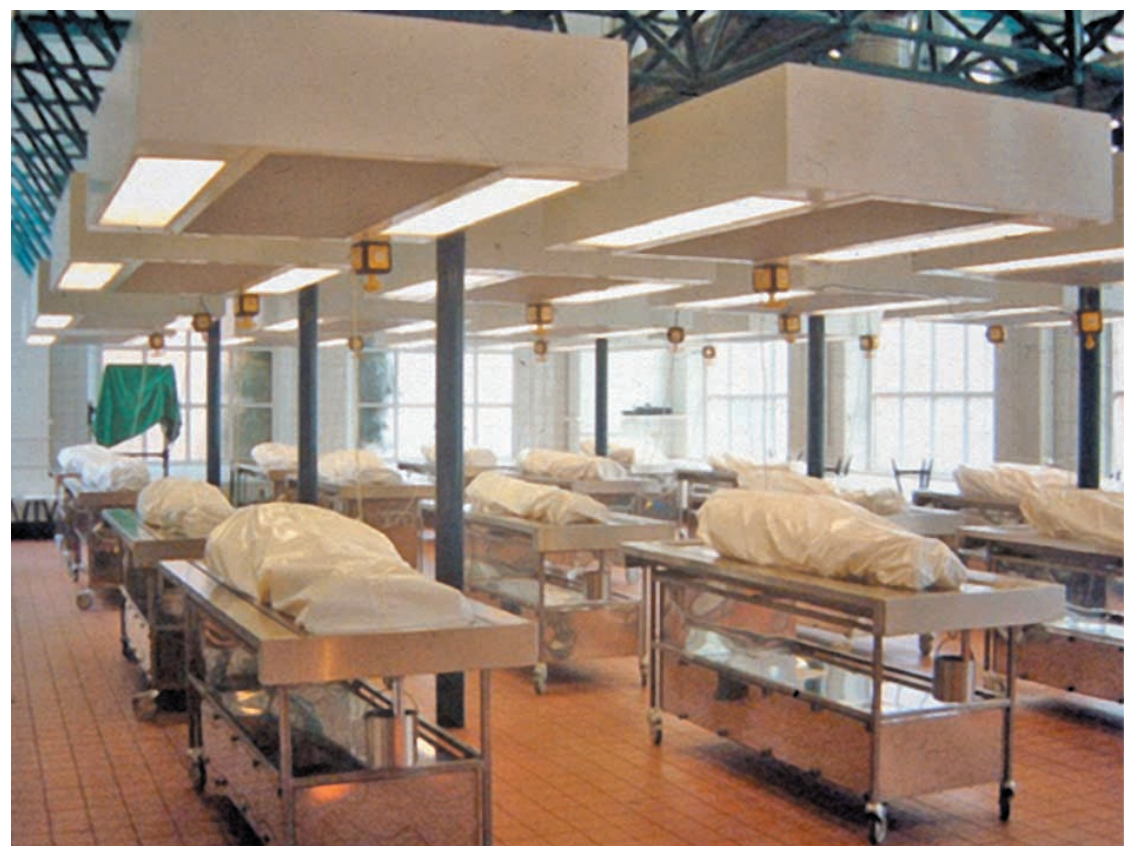

Fig. 23. Dissection hall, Institute of Anatomy, University of Greifswald 2002.

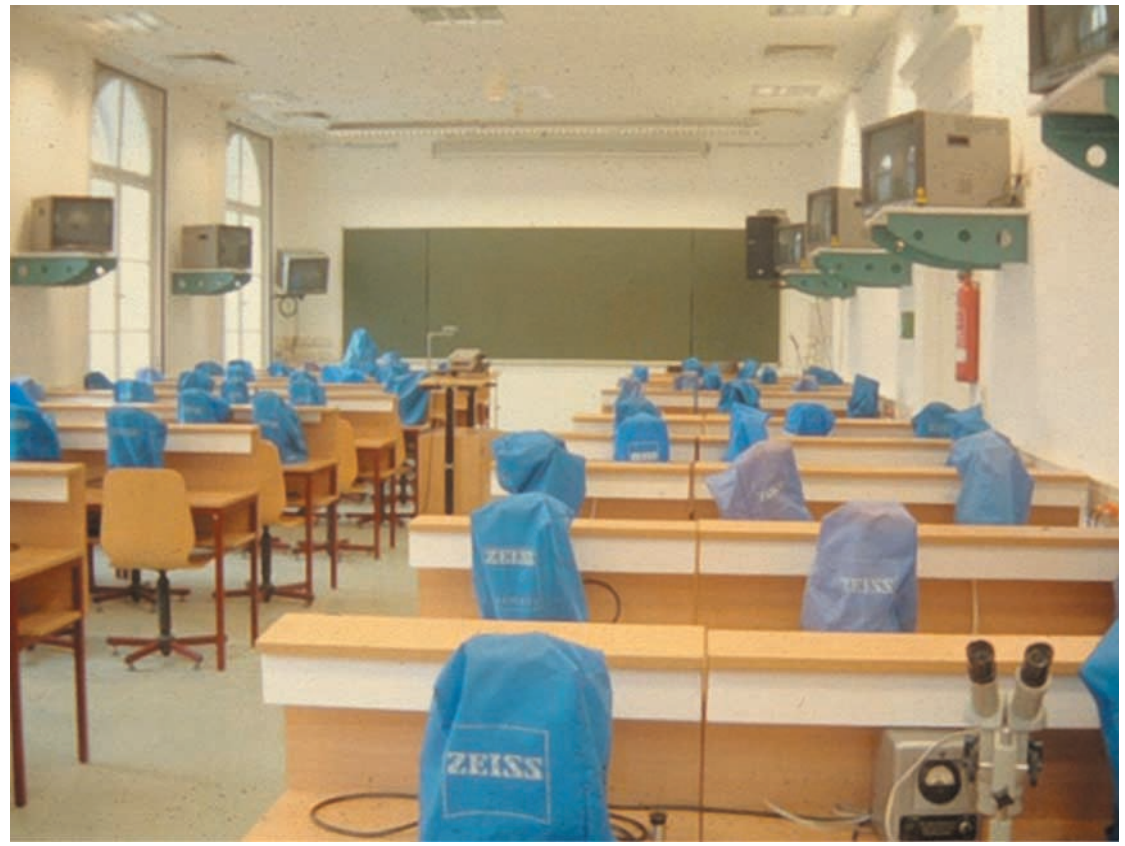

Fig. 24. Lecture hall of Histology, Institute of Anatomy, University of Greifswald. and got international priority because of its operational and architectural advantages. The first anatomical buildings of this type were established in Tübingen 1832/35, and Leipzig 1875, similar constructions followed in Breslau 1897, Marburg 1902 (Fig. 25b). Basel 1921 and Helsingfors 1928.

Department of Anatomy. A different development took place in the USA, where in contrast to the solitary anatomical institute anatomy got integrated into a large biomedical building as a Department of Anatomy.

Anatomical Auditory as Movie Theatre? Technical progress of audiovisual equipment was of great effect on a new start for the restoration of the auditory. The physiologist Czermak from Leipzig designed the model of a modern auditory 1872 and named it " Spectatorium" (Fig. 27). For this he required:

- Auditory in sufficient size, equipped with horseshoe shaped rows of seats, - convenient jump seats with good visibility,

- projector in a central position,

- technical facilities, such as electricity, gas, water, blackboard, screen, - demonstration room beneath the chairs or near to them

- dressing room below the chairs.

This was once and for all the end of the traditional anatomical auditory, since a modern anatomical lecture hall could not derive from the ancient Theatrum Anatomicum but from a modern cinema (Fig. 28a,28b).
The Anglo-Saxon-American type was a creation of the 19th century. The auditory was displaced from its central position to a peripheral location of the building and equipped with seats in semicircular arrangement. This was a break with the past and the auditory was seen on the same level with the dissection hall. The teaching region was separated from the area of research and administration, connecting passages were used for demonstrations. This type was the dominating creation
Anatomy up to date. In the history of ancient medicine "anatomy" was the performance of a "dissection". Up to now anatomy may be the investigation of biological structures with no other motive than description of form. Even so, such topographical anatomy has not remained insulated from technological progress; the usefulness of direct visual dissection persists, but its relatively crude results have become incalculably augmented by the advent of light 

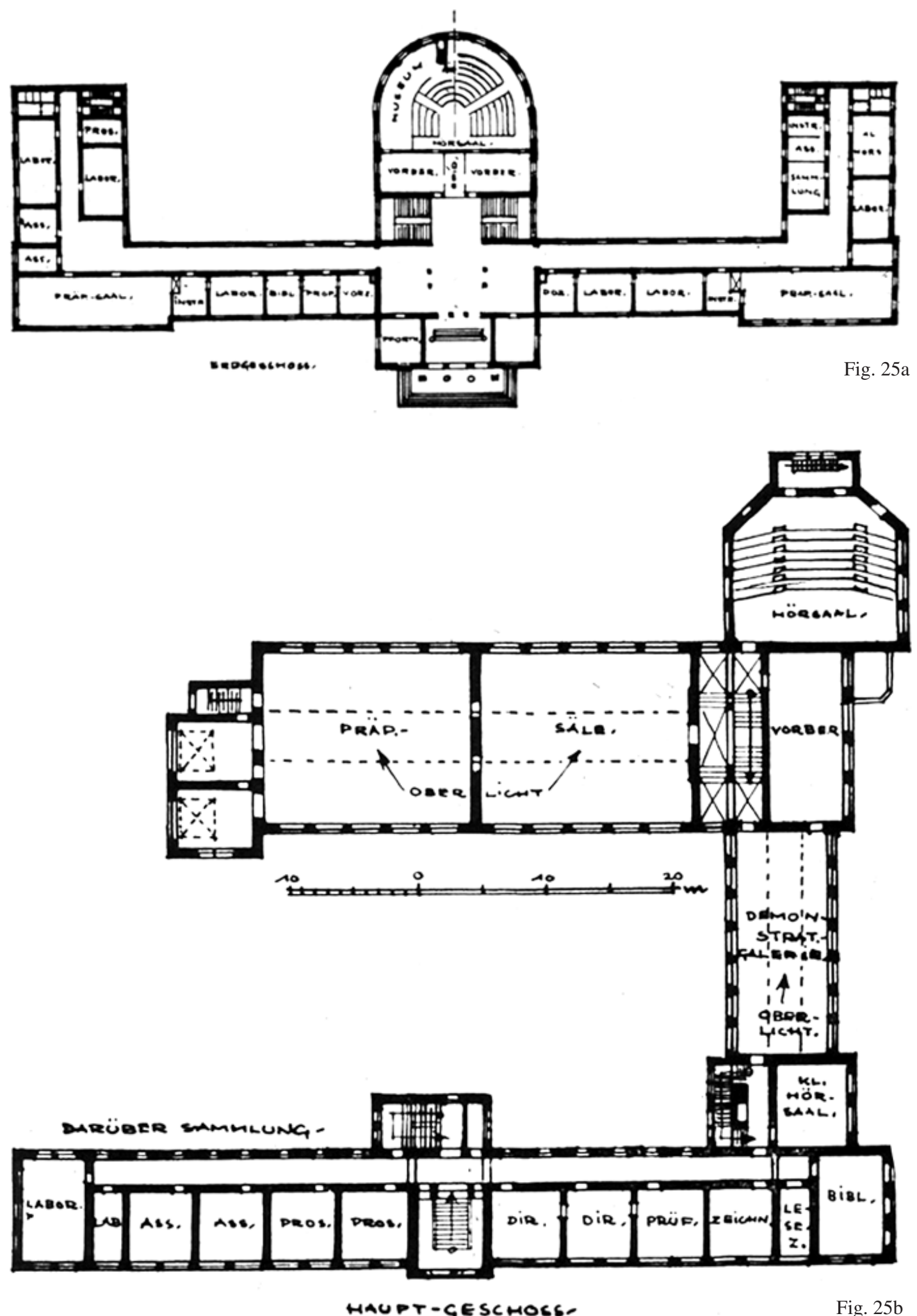

Fig. 25. Architectures of anatomical theatres after 1830. a. German European Type, University of Sofia 1876-78. b. Anglo Saxon Type, University of Marburg 1902. After G. Richter 1936. 

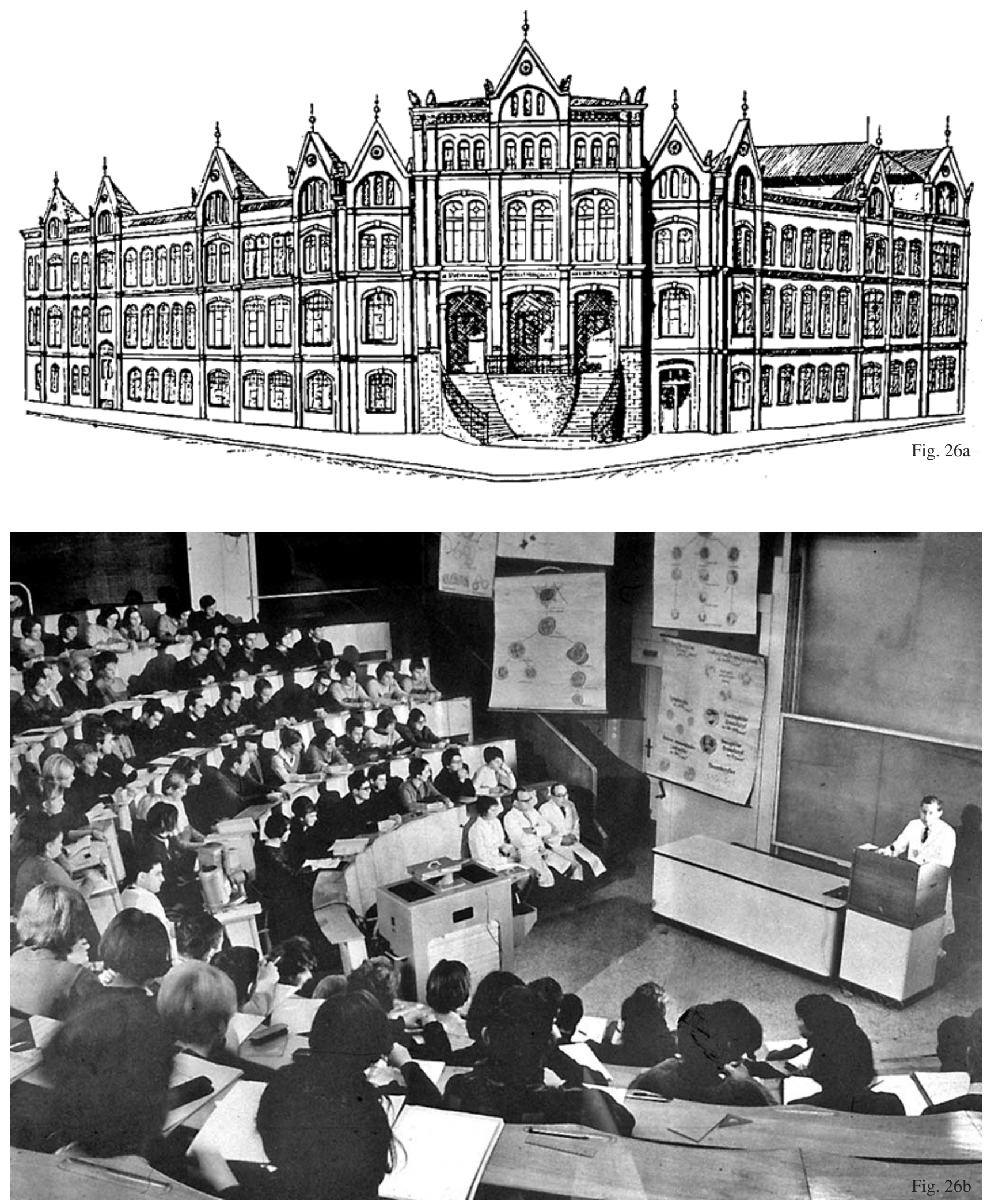

Fig. 26 .German European Type. a. Institute of anatomy and physiology, University of Rostock, 1876-1878, b. Lecture hall of the Intitue of anatomy Rostock 1965. 
Fig. 27

SCHUMACHER, G. H.

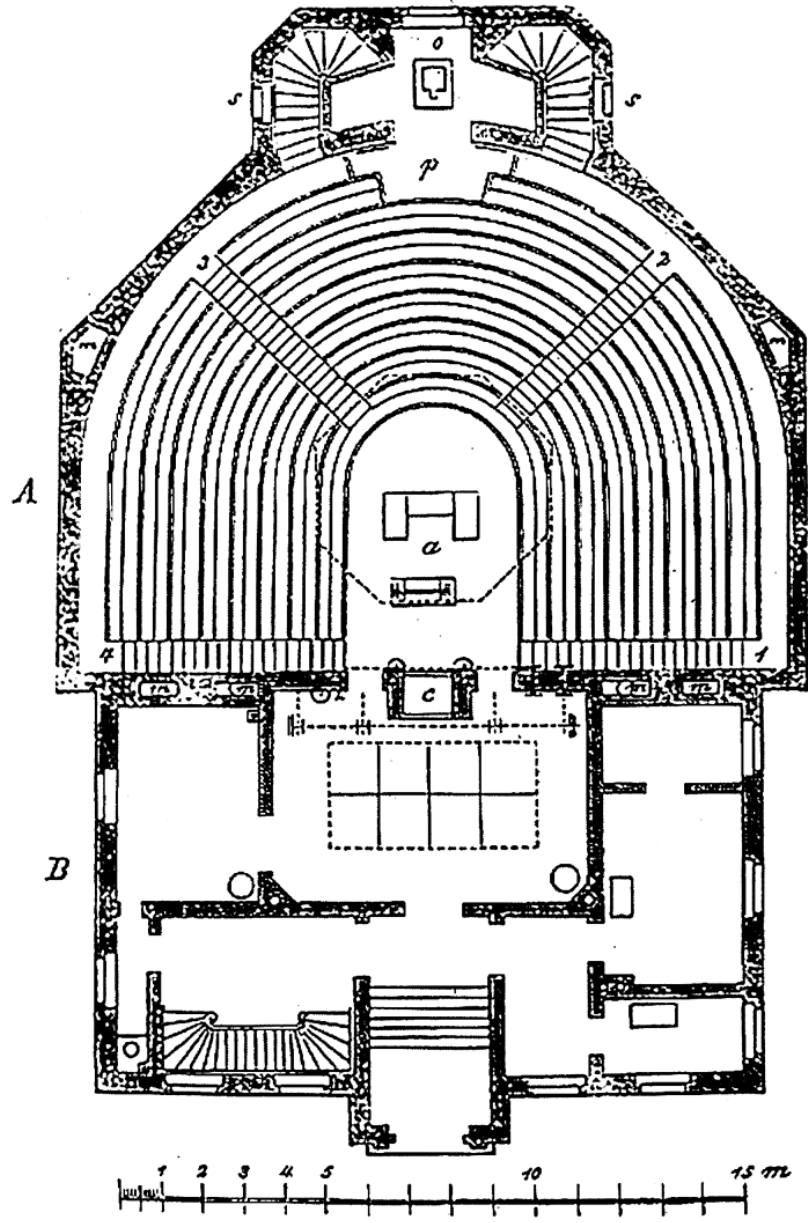

Fig. 27. Architectural design of a spectatorium, Czermak, Leipzig 1872. in G. Wolf-Heidegger and Cetto 1967.

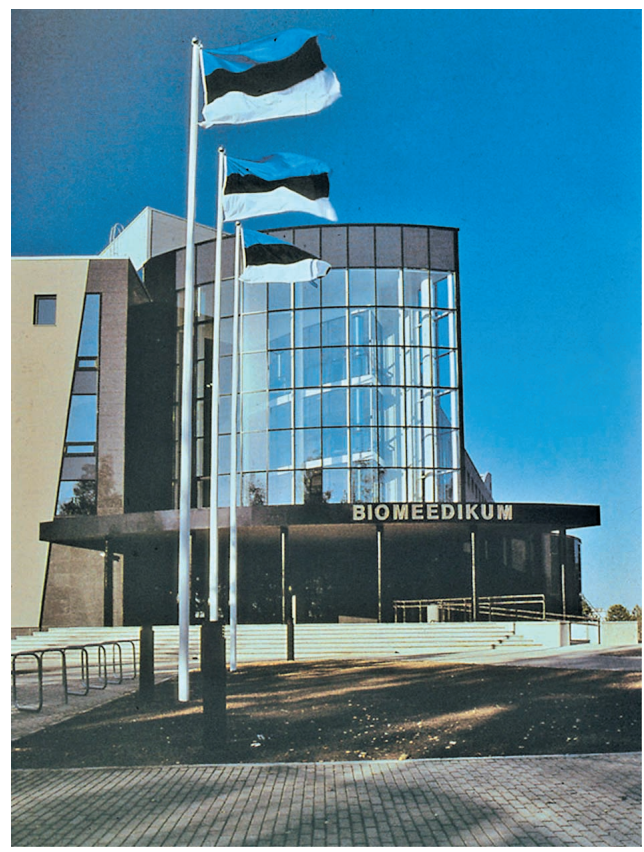

Fig. 28. University of Tartu, a. Biomedicum 1999, b. Lecture hall of the Biomedicum.

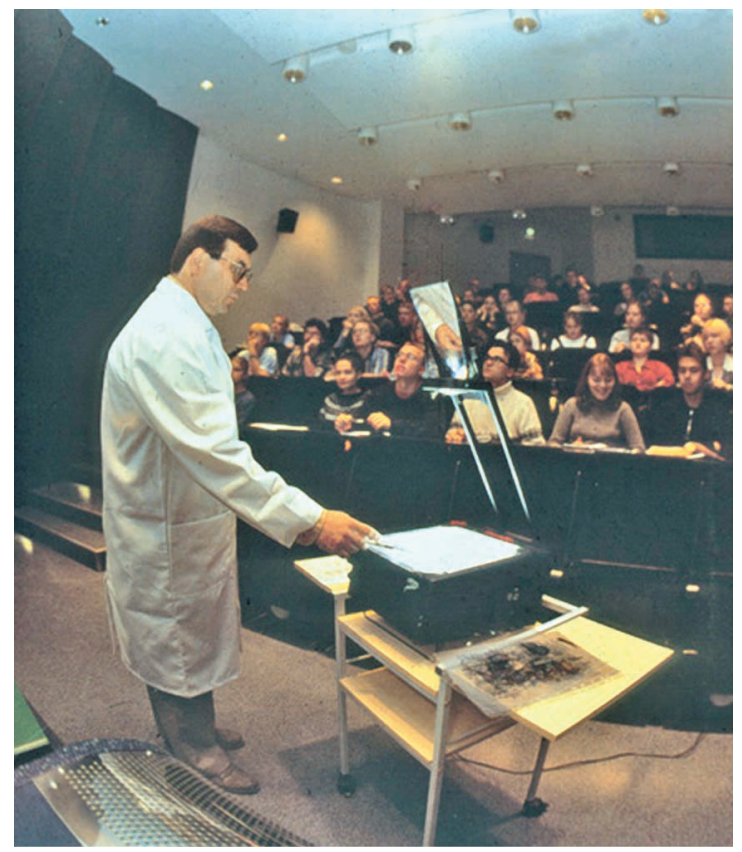

microscopy, microdissection, electron microscopy, histochemistry, radiology, autoradiography, and some other techniques. The application of these, has revealed great new fields of discovery. Histology and cytology, are true extensions of the parent discipline; others like electron microscopy, histochemistry and autoradiography, are merely techniques capable of providing particular types of data.

Problems of growth and differentiation, have led to particular studies of embryology, that includes not only ontogeny but also phylogeny. Embryology embraces gametogenesis, fertilization, blastogenesis, fetogenesis and organogenesis up to birth. In addition to the description of all development processes, experimental embryology is searching the causalities. Some other branches of research are cooperating with embryology, such as perinatology, human reproductive medicine, teratology and comparative embryology of animals.

Studies of growth emphasize the mutability of structures; and the dynamic nature of all living structures entails an inescapable relation between form and function. It is, of course, possible to consider form in isolation, an exercise of most limited value, though data of pure description may have particular applications. Applied anatomy is usually concerned with human structural observations which are useful in medicine, especially in surgical technique, but also in clinical diagnosis. Descriptive anatomy, however, has a far more extensive application in relation to function. The mere fact that topography can be described upon a regional or systematic basis necessarily entails functional considerations, for while the former is of interest in medicine, systematic anatomy is based upon recognition of 


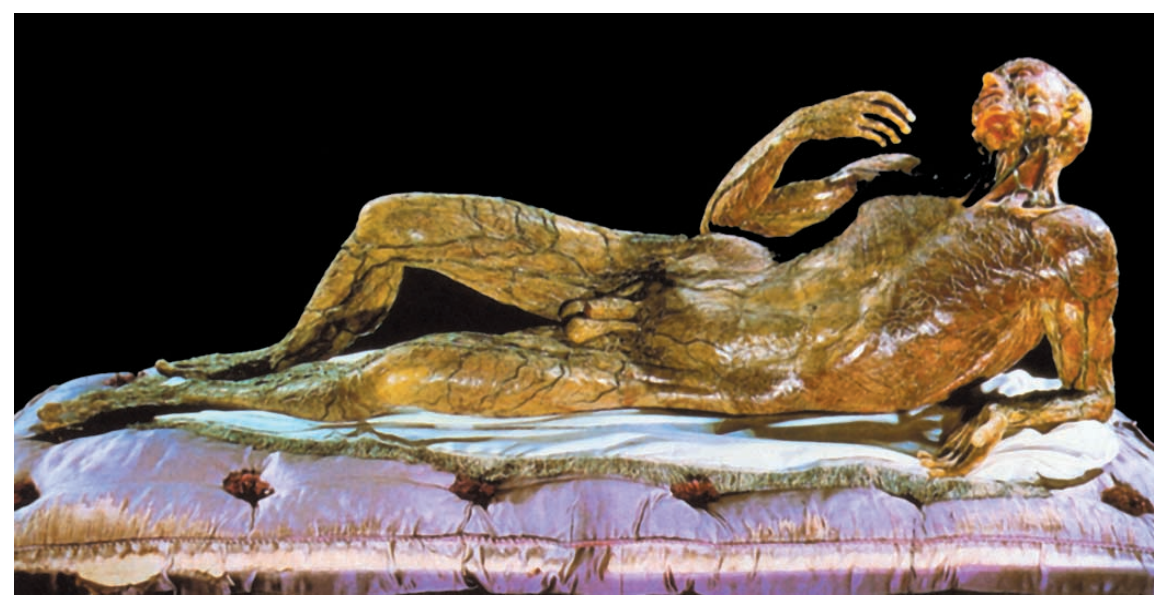

Fig. 29. Wax preparation of a human body, with exposition of the superficial lymph- and blood vessels. The Vienna Institute of the History of Medicine at the Josephinum.

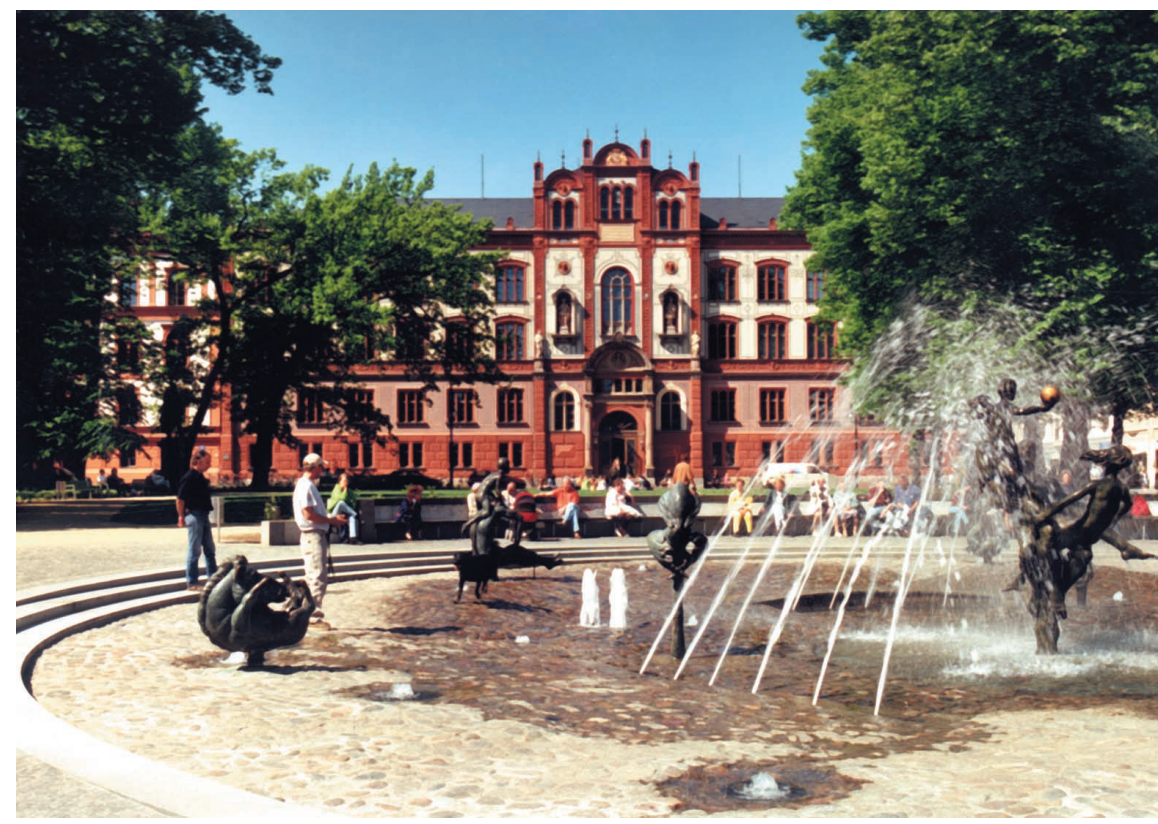

Fig. 30. Main Building of the University of Rostock, founded 1419, the oldest University in the North of Europe.

function. The locomotor system embraces structures directly concerned with movement of bones, articulations, ligaments, and muscles (Fig. 29). The study of these structures may be formalized as osteology, arthrology and myology. Similarly, neurology, which treats of the nervous system, including its sensory organs. The study of cardiovascular arrangements of organs, and tissues, are correlated as much by function as by structure. All systems are investigated at macroscopic, histological, cytological, ultrastructural and biochemical levels.

Experimental anatomy, experimental cytology and experimental embryology, have contributed greatly to the advancement of knowledge in the field of human anatomy.
In this century the conviction has increased among anatomists that isolated observation and description is not enough, and that an experimental approach to problems of structure is as necessary as in other biological sciences. In addition, the great advances in technique, especially in the study of finer detail, in living and developing organs, tissues and cells, have enlarged the scope of anatomy far beyond the parent stem of macroscopic structures. These advances have engendered a spate of new specialities, such as cell biology, histology, embryology, neurology, electromyography, kinesiology, ergonomics and so on, to a degree dependent only upon the choice of individual minds and the canalization of techniques. The expanding scope of structural knowledge and the exacting demands of more elaborate techniques do indeed dictate such specialization; but all such knowledge remains a continuum, except insofar as extensive gaps of ignorance and uncertainty persist. Unfortunately, and perhaps particularly in the medical sphere, the compartmentalization of anatomy into several disciplines or subjects tends towards disintegration. To study such region as a limb, in all its proportions, activities, and even evolution, including its major structures, and to proceed to the microscopic, ultrastructural and ultimately biochemical details of its cells and tissues, appears to us a continuous process. Unfortunately, these different levels of organization and function are perforce usually considered in separate departments, laboratories, lectures and books. The defects of this compartmentalization are widely recognized, and have resulted in much effort to integrate teaching.

ACKNOWLEDGEMENT. I wish to thank Veronica Antipova, D.D.S. for her inspiration and support on this publication and Kerstin Baier for her excellent computer assistance.

In honour of the University of Rostock, which is preparing her 600 anniversary in 2019 (Fig. 30). 
SCHUMACHER, G. H.

SCHUMACHER, G. H. El Theatrum Anatomicum en la historia y hoy. Int. J. Morphol., 25(1):15-32, 2007.

RESUMEN: La disección de cadáveres humanos fue introducida en Alejandría alrededor de 300 A.C. y perfeccionada por Herófilos (335-255) durante 30 o 40 años. Estas disecciones pararon hasta Vesalio (1514-1564) cuando inició su trabajo durante el Renacimiento en Occidente. Él reemplazó las teorías dominantes de Galeno (130-201), quien obtuvo sus conocimientos de secciones de animales. En los siglos 14 y 15 las disecciones humanas fueron realizadas en pequeñas lugares. Los primeros diseños del teatro anatómico fueron preparados por Alejandro Benedicto en Padua en 1497 y por Carolus Stephanus de París en 1564. Los primeros teatros anatómicos temporales sur gieron en Italia en el siglo 16, desde donde viene el término Theatrum Anatomicum. En 1594, el primer teatro anatómico permanente fue abierto en Padua, convirtiéndose en el modelo para muchos edificios anatómicos. El tipo más representativo se construyó en Bolonia en 1649, pero el primer teatro anatómico solitario se originó en París en 1694. El progreso del conocimiento anatómico durante el siglo 18 dio a luz la creación de institutos anatómicos, en algunos países europeos. Ellos presentaron diferentes arquitecturas. El campo común a todas ellas fue la separación de las instalaciones entre la enseñanza y la investigación. Los elementos estilísticos vinieron del tipo axial, e. g. el Instituto de Senckenber g en Frankfurt en 1776 y el Instituto de Dorpat (1803-1825/27) y del tipo de Sömmering en Greifswald (1854/55). El progreso de las ciencias en el siglo 19 dio gran impulso para muchas soluciones arquitectónicas, éstas eran tipo alemán-europeo y el tipo anglo-sajón-americano. El progreso técnico del equipamiento audiovisual causó un nuevo comienzo para la restauración del auditorium en un "Spectatorium" en 1872. El auditorio fue desplazado desde su posición central y cambiado a un cine con el equipamiento audiovisual. Esto fue de una vez por todas el fin del tradicional Theatrum anatomicum.

PALABRAS CLAVE: Historia de la Medicina; Herófilos; Disección anatómica humana; Galeno; Vesalio.

\section{REFERENCES}

Aumüller, G. Zur Geschichte der Anatomischen Institute von Kassel und Mainz. Med. Histor. J., 5:268-88, 1970.

Benedictus, A. Anatomiae, Paris, 1514.

Czermak, J. N. Gesammelte Schriften II, Leipzig, 1879.

Lycosthenes, C. Prodigiorum ac ostentorum chronicum. Basel, H. Petri, 1557.

Richter, G. Das Theatrum anatomicum. Abh. Gesch. Med. Naturwiss, 16:1-156, 1936.

Schumacher, G. H. \& Wischhusen, H. G. Anatomia Rostochiensis, Akad. Verlag, Berlin, 1970.

Sömmering, S. T. Gedanken und Plan zur Errichtung eines bequemen Zergliederungshauses. Baldingers Mediz. J., 5: 1-12, 1787.

Stephanus, C. De Dissectione partium corporis. Paris, 1545.

Wegner, R. N. Zur Geschichte der Anatomischen Forschung an der Universität Rostock. Wiesbaden, 1917.

Wiltse, L. L. \& Pait, G. T. Herophilus of Alexandria (325255 B. C.). Lippincott Williams \& Wilkins 23, 19041914, 1998.

Wolf-Heidegger \&. A. M. Cetto. Di Theatrum Anatomicum in History and Today Gert-Horst Schumacher, Institute of Anatomy, University of Rostock.
Correspondence to:

Prof. em. Dr. sc. med., Dr. med dent. Gert-Horst Schumacher Gerhart-Hauptmann-Strasse 25

D-18055 Rostock

GERMANY

Phone \& Fax: ++ 49 (0) 3814923611

Email: gert-horst.schumacher@medizin.uni-rostock.de

Received: 22-11-2006

Accepted: 03-01-2007 